\title{
Age, distribution, and significance within a sediment budget, of in-channel depositional surfaces in the Normanby River, Queensland, Australia.
}

\author{
Pietsch, T.J.*, Brooks, A.P., Spencer, J., Olley, J.M., Borombovits, D. \\ Australian Rivers Institute, Griffith University, Nathan, QLD 4111, Australia \\ *Corresponding author. Tel: +61 73735 7153; Fax: +61 737357459. \\ E-mail address: t.pietsch@griffith.edu.au (T.J. Pietsch)
}

\begin{abstract}
We present the results of investigations into alluvial deposition in the catchment of the Normanby River, which flows into Princess Charlotte Bay (PCB) in the northern part of the Great Barrier Reef Lagoon. Our focus is on the fine fraction $(<\sim 63 \mu \mathrm{m})$ of alluvial deposits that sit above the sand and gravel bars of the channel floor, but below the expansive flat surface generally referred to as the floodplain. Variously described as benches, bank attached bars or inset or inner floodplains, these more or less flat-lying surfaces within the macro-channel have hitherto received little attention in sediment budgeting models. We use high resolution LiDAR based mapping combined with optical dating of exposures cut into these in-channel deposits to compare their aggradation rates with those found in other depositional zones in the catchment, namely the floodplain and coastal plain. In total 59 single grain OSL dates were produced across 21 stratigraphic profiles at 14 sites distributed though the $24226 \mathrm{~km}^{2}$ catchment. In-channel storage in these inset features is a significant component of the contemporary fine sediment budget (i.e. recent decades/last century), annually equivalent to more than $50 \%$ of the volume entering the channel network from hillslopes and subsoil sources. Therefore, at the very least, in-channel storage of fine material needs to be incorporated into sediment budgeting exercises. Furthermore, deposition within the channel has occurred in multiple locations coincident in time with accelerated sediment production following European settlement. Generally, this has occurred on a subset of the features we have examined here, namely linear bench features low in the channel. This suggests that accelerated aggradation on in-channel depositional surfaces has been in part a response to accelerated erosion within the catchment. The entire contribution of $\sim 370$ kilotonnes per annum of fine sediment estimated to have been produced by alluvial gully erosion over the last $\sim 100$ years can be accounted for by that stored as in-channel alluvium. These features therefore can play an important role in mitigating the impact on the receiving water of accelerated erosion.
\end{abstract}

\section{Introduction}

The sediment budget concept has been a central organising principle within the discipline of geomorphology since at least the 1970s (Dietrich and Dunne, 1978; Dunne and Leopold, 1978), with the concept increasingly refined in subsequent decades (e.g. Walling et al., 2002; McKergow et al., 2005). In essence a sediment budget provides a method of accounting for sediment inputs and outputs through a drainage network. It enables the primary sources of sediment and the sediment transport pathways to be identified, and is useful for highlighting data needs and system understanding (or lack thereof).

Alluvial deposits that sit within the channel boundary but are too high to be considered part of the mobile bed have recently been the subject of renewed research effort in Australia, especially in relation to their role within sediment transport pathways (e.g. Rustomji and Pietsch, 2007; Hoyle. et al., 2008, 2012; Hughes et al., 2010; Erskine et al., 2009, 2012; Wasson et al., 2010; Croke et al., 2013; Thompson and Croke, 2013). Such deposits are common in river systems bounded by extensive Pleistocene age alluvial surfaces which are not active under the current hydrological regime and tend to give rise to compound channels. This type of channel is increasingly being referred to as a 'macro-channel', sensu van Niekirk et al, (1999), who initially applied the term to compound bedrock channels in 
South Africa. The term was first used in an Australian context by Hoyle et al., (2008) to describe the morphology of compound channels bounded by Pleistocene terraces in the Hunter River. There is a growing realisation that understanding the dynamics of these inset deposits is crucial to understanding the transport of sediments from and through catchments (e.g. Hoyle et al., 2012; Bartley et al., 2014). The perceived importance of these deposits may, in part, be due to the highly episodic nature of flow in many Australian catchments (Finlayson and McMahon, 1988; Kemp, 2004; Peel et al., 2004; Rustomji et al., 2009). In these catchments, flow over the high floodplain is a rare occurrence and deposition thereon consequently represents an insignificant part of the sediment budget in most years. Our observations of large expanses of depositional zones within the channels of the Normanby Catchment in northern Queensland, Australia, lead us to hypothesise that they may be a more significant sediment store than the higher alluvial surface traditionally termed the floodplain, or at least significant enough that excluding them from a catchment sediment budget would result in it being significantly in error. This study seeks to test this hypothesis. Also, as in-channel aggradation, especially that occurring on low-set linear benches aside the channel, is unlikely to be constant through time we look to understand the longer term dynamics of bench creation and removal. Of particular interest is the relationship (coincident or otherwise) between the timing of bench establishment and growth, and the adoption of European management practices in the catchment.

In this paper we use a variety of methods to allow us to describe the significance of in-channel features, including benches, in the sediment budget of the Normanby Catchment. We use optical dating to determine aggradation rates, particle size analysis and stratigraphic description of bench, inset floodplain and floodplain deposits to examine silt and clay concentrations, and an automated analysis of LiDAR data to determine the distribution of inchannel depositional surfaces throughout the catchment.

This paper builds on the previously published reports and papers (Brooks et al 2013.; 2014a,b,c; Olley et al. 2013; in prep) that arose out of an Australian Government funded project that sought to parameterise with newly collected empirical data, at higher spatial and temporal resolution, a new sediment budget model for the Normanby. We focus on the distribution and rates of aggradation of in-channel deposits as these were not included in the previous sediment budgeting exercises. We also include comparable investigations into the floodplain and the broad coastal plain at the very bottom of the catchment. These data allow the rates of deposition and storage of fine sediment within the channel to be placed in a broader context.

Experience in catchments elsewhere in Australia (e.g. Rustomji and Pietsch, 2007; Thoms and Olley 2004; Hughes et al., 2010) suggests that bench development may be a direct response to increases in catchment sediment discharge. Many studies conducted in SE Australia (New South Wales and Victoria) have shown large increases in erosion and sediment delivery as a result of land use changes following European settlement about 180 years ago (e.g. Prosser et al., 1994; Prosser and Winchester, 1996; Brooks and Brierley, 1997, 2000; Wasson et al., 1998; Scott, 2001).

European settlement occurred in the Normanby in the late 19th century, with the first widespread gold mining occurring in the 1870s with associated development shortly thereafter, including introduction of widespread cattle grazing. In the adjoining Mitchell catchment, the onset of significant gully erosion is closely correlated with the arrival of cattle (Shellberg et al., 2010, 2013). Evidence from gully fill sequences presented in Brooks et al. (2013) shows that similar changes in erosion rates accompanied settlement in the Normanby.

The development of within channel depositional surfaces is not necessarily a sign of settlement-induced increases in sediment discharge. In catchments of southeast Australia there is abundant evidence of the periodic removal and rebuilding of within channel features, completely unrelated to changes in catchment management (e.g. Eriksson et al., 2006). Channel evolution in these systems is characterised by periodic channel enlargement by infrequent large magnitude floods, countered by gradual contraction in the intervening periods (Nanson and Erskine, 1988; Rustomji, 2008; Rustomji et al., 2009). Although the Normanby has a highly seasonal discharge by virtue of its tropical setting, it has a comparatively low variability flow regime at the decadal scale; in contrast to the so called flood and drought dominated flow regimes of many of the coastal catchments of southeastern Australia (Warner and Erskine, 1988; 
Page 3 of $\mathbf{4 3}$

Rustomji et al., 2009) where the cyclic expansion and contraction described above are most apparent. An alternative explanation for bench formation and subsequent destruction was put forward by Wasson et al., (2010) for the Daly River in Australia's Northern Territory, in which it is suggested that the formation, and recent erosion, of benches is a response to shifts in the hydrological regime. They observe bench ages extending back several hundred years, with a recent period of widespread bench erosion (though not full destruction) being coincident with an observed increase in rainfall and discharge since about AD 1990. In this study we will also consider whether this is a potential explanation for bench dynamics in the Normanby.

\section{Study site}

The Normanby catchment, including the major tributaries of the Hann, North Kennedy, Annie and Morehead Rivers, covers an area of $24226 \mathrm{~km}^{2}$ in tropical north Queensland, Australia (Fig. 1). Mean annual run-off based on modelled and empirical data from 1986 to 2009 is estimated at 4,600 $\mathrm{GL} \mathrm{year}^{-1}$. The climate is characterised by extreme rainy summer and dry winter seasons with $95 \%$ of annual rainfall occurring between the months of November and April. Consisting of predominantly low relief plains in the north and undulating rises and dissected plateaus in the south, the Normanby drains into Princess Charlotte Bay (PCB) which in turn opens onto the Great Barrier Reef (GBR) lagoon. Fig. 2 provides a schematic representation of the arrangement of riverine landscapes within the catchment and the downstream development of the channel floodplain relationship. In the upper parts of the catchment, approximately encompassed by Reach A in Fig. 1, and more or less replicated in the uppermost catchments of the tributaries of the Normanby River, the channel is flanked by linear bench features of Late Holocene age (decades to centuries old) and inset floodplain units that, though still inundated, are predominately Early Holocene in age (the general age constraints described in this section are a brief summary of results discussed in detail below and additional dates provided in Brooks et al 2013). Channel, linear bench and inset floodplain together sit entrenched within Late Pleistocene sediments that form the extensive flat alluvial surfaces that extend in many places several kilometres distal to the channel. These 'floodplains' in the upper reaches are not genetically related to the contemporary flow regime, generally dating to 20-30 ka and are constrained within bedrock hills. These confining Pleistocene deposits have the superficial appearance of forming the high 'banks' of these inset features, which collectively are referred to as a 'macro-channel'. However, as outlined in Brooks et al. (2014a), these high banks are shown to be relatively stable despite in many cases having the appearance of raw 'cut bank' faces. Further downstream (Reach B in Fig. 1) the influence of bedrock diminishes and Holocene aged alluvial floodplains are interspersed between low sand plains derived from underlying Tertiary sandstone. Further downstream (Reach C) estuarine channels meander through broad Holocene floodplains, with low set mangrove flats sitting within the meander train below the floodplain proper. Finally, the Normanby and its downstream distributaries (The North Kennedy and Bizant Rivers) cross a wedge shaped coastal plain showing evidence of wholesale stripping, with remnant pedestals distributed across the plain defining the level of the pre-existing surface. Thus it can be seen that the nature of the 'floodplain' and its relationship to the modern channel changes dramatically downstream, with consequent impacts on sediment distribution. The evolution of the macro-channels in reaches $A$ and $B$, and indeed the erosion of the coastal plain and associated upstream entrenchment, is the subject of ongoing research and will not be dealt with directly here.

Despite retaining much of its 'natural' vegetation cover, and being very sparsely populated $(<500$ permanent residents), the Normanby catchment has been identified as one of the most significant contributors of suspended sediment to the GBR (Prosser et al., 2001; Brodie et al., 2003), though this assertion has been challenged (Fabricius et al., 2005), as have the nature of the sources and the model assumptions used to derive the catchment estimates (Brooks et al., 2013, 2014a,b,c; Olley et al., 2013). Many of the earlier conclusions as to the significance of the Normanby as a source of sediment to the GBR arose out of desktop sediment budget modelling exercises. 
Page 4 of 43

\section{Methods}

In this section we discuss data collection methods. Description of the methods used to incorporate these data into a sediment budget is provided in the Discussion.

\subsection{Site selection}

Five bench sites distributed throughout the catchment, judged to be broadly representative of the styles of inchannel bench found within the Normanby catchment, were selected for stratigraphic investigation and assessment of aggradation rate. A single inset floodplain beside the West Normanby River at Kings Plains (KPWN-3) was chosen as broadly representative of the larger features that sit at intermediate elevations between linear benches aside the channel and the floodplain proper. An additional site (East Normanby) was selected for intensive investigation of the variation in aggradation rate within a channel; whereby multiple aggradation rates for different surfaces with different elevations above the thalweg were determined. A further nine floodplain sites, generally exposures in stream banks, were selected for determination of aggradation rate on the high floodplain. Finally, two sites on the broad coastal plain at the lowermost part of the catchment were included for investigation. Sampling locations are shown in Fig. 1.

\subsection{Field stratigraphy}

At each sampling location pits were hand dug or fresh faces were cut in existing exposures, to an average depth of $2.5 \mathrm{~m}$ (see stratigraphic plots in Figs. 7-15 for actual depths at each site). The coastal plain section was supplemented by hand augering to depth. Stratigraphic descriptions were made in the field, supplemented by investigation of sediments under a binocular microscope and particle size analysis.

\subsection{Feature mapping using LiDAR}

Between May and August 2009, as part of a larger study of the catchments (Brooks et al., 2013), Terranean (now RPS) acquired airborne Light Detection and Ranging (LiDAR) elevation data for 33 blocks (Fig. 1) covering an area of $783 \mathrm{~km}^{2}$ (3.2\% of the catchment). Flight lines were designed to achieve a minimum point density of 2.3 points $\mathrm{m}^{-2}$ and $43 \%$ overlap over all blocks. Final point density was 4.7 points $\mathrm{m}^{-2}$. The flying height was (nominally) $600 \mathrm{~m}$ above ground level. The LiDAR points were classified as ground and non-ground points using automatic filtering followed by interactive checking and re-classification. The classification was performed using TerraScan software. Once the point clouds had been formed and classified, raster surfaces were generated from the LiDAR data. The rasters were provided to the authors by Terranean in ASCII grid format. The digital elevation model generated from the LiDAR data had a $1 \times 1 \mathrm{~m}$ horizontal resolution and $0.15 \mathrm{~cm}$ vertical resolution. An automated approach to bench delineation using these data within ArcGIS was developed. Firstly, we derived a 'flat area' layer for each of 33 LiDAR blocks by selecting those areas with less than $8^{\circ}$ slope, presuming these to be the zones of maximum potential deposition (Fig. 3). To reduce processing times, this layer was clipped using a hand digitised polygon that incorporated the channel and enough of the upper floodplain to ensure no component of the channel was excluded via operator bias as regarding what constitutes the channel edge. We have analysed all channels within the Australian Hydrological Geospatial Fabric (AHGF) (Australian Bureau of Meteorology, 2013) that intersect our LiDAR blocks. We have found it convenient to follow the AHGF classification of channels as 'major' and 'minor' (see Results and Discussion). An elevation above thalweg was then determined for each $1 \mathrm{~m}$ grid cell comprising the 'flat area' using the 'Spatial Join' function within ArcGIS. Each grid cell was compared in elevation to the nearest part of the channel thalweg, with the thalweg digitised by hand. In many places the true thalweg could not be identified due to the presence of standing water, in these cases the thalweg was simply mapped as the centreline of the waterbody. Though this introduces a small inaccuracy, it is not considered significant as, in most cases, the depth of standing 
water during the dry season (when the LiDAR data was collected) is shallow $(<0.5 \mathrm{~m}$ ) in comparison to the overall relief of the channel bed $(>2 \mathrm{~m}$ ). For smaller tributary channels, where bed relief was very much less than $2 \mathrm{~m}$, the channels were universally dry, hence thalwegs could be readily identified.

A frequency distribution relating 'flat area' elevations relative to the height above the thalweg was then developed (Figs. 3E and 4D). Presented in this way, the height of the floodplain is clearly marked by a peak in the frequency histogram centred on the average depth of the macro-channel. The other reoccurring feature of these plots is a peak centred on zero, with the positive spread in this peak representing the bed relief and unavoidable artefacts of the use of a triangulated irregular network (TIN) model for the water surface, where the line of the thalweg included some sections of waterbody. LiDAR provides a very low point density for water surfaces, hence the TIN model produced for water surfaces has a characteristic corrugated structure. In the larger channels, the peak due to the bed relief is distinct from that due to the water surface, hence two low elevation peaks occur, as in Fig. 3E. In most plots distinct concentrations in elevation between the thalweg and floodplain peaks also occur, with these appearing as discrete benches or inset floodplains in the field. Where no flat areas exist within a channel, a characteristic ushaped distribution occurs; whereas large areas of gently sloping surface or large numbers of discrete flat areas with closely spaced elevations, result in a continuum between thalweg and floodplain with no particular peaks observable. Fig. 3 E provides examples of peaks associated with discrete benches and bench elevation continuums e.g. between 9 and $12 \mathrm{~m}$ elevation above the thalweg.

The flat-area-height above thalweg histograms allow description of the distribution of within channel surfaces; and calculation of the total area of within channel depositional area (the area below the curve). In this way we overcome problems of definition and delineation associated with mapping features exactly accordant with previous definitions of 'bench' or 'bar' or 'inset floodplain' (e.g. those provided by Erskine et al., 2009 and Vietz et al., 2004; 2012). The strict application of any of these previously proposed definitions would:

i. require an unfeasibly onerous mapping program,

ii. be subject to operator bias, and

iii. result in the omission of surfaces that, whilst not of clearly definable form nonetheless, operate as zones of potential deposition.

We are thus using the term 'within channel depositional surface' to mean all relatively flat surfaces above the mobile bed but below the extensive alluvial surface which may be either true floodplain (i.e. currently active) or terrace (no longer inundated under the current climatic regime). The 'mobile bed' is identified as areas being free of vegetation and having high reflectance values in imagery collected simultaneously (i.e. from the same airborne platform) as the LiDAR data. The 'floodplain' is that feature marked by the largest peak in the frequency histogram of elevations relative to the thalweg. Note the absolute scale of this peak is simply a function of the size of the buffer used to encompass each channel segment (described above).

\subsection{Particle size analysis}

All samples collected for optical dating had sub-samples collected for particle size analysis, undertaken using a Malvern Mastersizer 2000 and protocols developed by the Queensland Government Department of Science, Information Technology, Innovation and the Arts (DSITIA) Chemistry Centre. Samples were mechanically agitated and ultrasonically dispersed before and during measurement.

\subsection{Optical dating}

In total 59 samples were collected for optical dating by driving stainless steel core tubes ( $4 \mathrm{~cm}$ diameter) into cleaned exposures or the base of boreholes. Sample preparation was designed to isolate pure extracts of 180-212 $\mu \mathrm{m}$ light safe quartz grains, collected from the centre of the core tubes, following standard procedures (e.g. Aitken, 1998) under subdued red light. Treatments were applied to remove contaminant clays, carbonates, feldspars, 
organics, heavy minerals and acid soluble fluorides. The outer $\sim 10 \mu \mathrm{m}$ alpha-irradiated rind of each grain was removed by etching each sample in $48 \%$ hydrofluoric acid.

Single-grain equivalent dose $\left(D_{\mathrm{e}}\right)$ values were determined using the modified single aliquot-regenerative dose (SAR) protocol of Olley et al. (2004) and Risø instrumentation described therein, in combination with the acceptance / rejection criteria provided in Pietsch (2009). An additional test based on examination of variations in the response to the test dose was also incorporated. Grains were rejected if either of the second or third Test Dose signals varied in sensitivity from the first Test Dose (associated with the Natural Dose) by more than $20 \%$.

The age modelling approach of Galbraith and co-workers (Galbraith and Laslett, 1993; Galbraith et al., 1999; Roberts et al., 2000) was used to determine a burial dose from the population of single grain $D_{\mathrm{e}}$ values. First the central age model (CAM) was used to determine the over-dispersion $\left(\sigma_{d}\right)$ for each sample, with $\sigma_{d}$ representing the degree of spread in the data beyond that which can be explained by known sources of uncertainty (i.e. measurement uncertainty on each individual single grain $D_{\mathrm{e}}$ ). Non-zero $\sigma_{\mathrm{d}}$ values are almost universally found for single grain dose distributions. The greatest component of this is traditionally attributed to partial bleaching (e.g. Olley et al., 2004) however there are other important contributors, most notably $\beta$-dose heterogeneity (Nathan et al., 2003), but also variations in instrument uncertainty which has been shown to be sample dependent (Jacobs et al., 2006; Pietsch, 2009). Once $\sigma_{d}$ for each single grain dose population has been defined using the CAM, the minimum age model (MAM) is applied to identify the component of the dose distribution which represents those grains fully bleached at deposition. To do so requires adding in quadrature to each single grain $D_{\mathrm{e}}$ error, the absolute percentage of $\sigma_{\mathrm{d}}$ considered to originate from sources other than partial bleaching. In other words, it is necessary to determine how overdispersed the single grain $D_{\mathrm{e}}$ population would be, even if it was completely bleached at burial, prior to application of the MAM. Here we have determined the $\sigma_{\mathrm{d}}$ likely to exist within well bleached populations by identifying the lower limit of $\sigma_{\mathrm{d}}$ across all samples, with our assumptions being that at least some of our samples will be fully bleached, but that all samples will have the same degree of $\sigma_{\mathrm{d}}$ caused by other factors. Some proportion of our samples are likely to be well bleached and these should all have a consistent $\sigma_{\mathrm{d}}$ value, with this being a function of measurement conditions, and the level of heterogeneity in the dose field within bench and floodplain deposits of the Normanby. Examination of the distribution of $\sigma_{\mathrm{d}}$ from all samples lead to the use of an over-dispersion of $20 \%$, prior to application of the MAM.

Lithogenic radionuclide activity concentrations were determined using high-resolution gamma spectrometry (Murray et al., 1987), with dose rates calculated using the conversion factors of Stokes et al. (2003). $\beta$-attenuation factors were taken from Mejdahl (1979). Cosmic dose rates were calculated from Prescott and Hutton (1994) and long term water contents were estimated from observation of the range of measured water contents and consideration of the sampling location relative to the water table. Concentrations of ${ }^{238} \mathrm{U},{ }^{226} \mathrm{Ra}$ and ${ }^{210} \mathrm{~Pb}$ are consistent with secular equilibrium in most samples. The minor secular disequilibrium observed in some samples is not sufficient to result in the calculation of an age significantly different from that which would result from assuming equilibrium conditions to have persisted throughout the burial period. Hence, for simplicity, the ages have all been calculated using the asmeasured radionuclide contents.

\section{Results}

\subsection{In-channel depositional surface delineation, distribution and form}

Large flat alluvial surfaces below the upper floodplain are widespread in the Normanby catchment, occurring in virtually all reaches of the major channels and within the largest of the 'minor' channels. Fig. 4B illustrates a typical example, showing within channel benches extending on both sides of the low channel, and occupying, in this case, more than $100 \mathrm{~m}^{2}$ for each linear metre of channel thalweg. It may be argued that the surface on the left flank of the channel at this location is too extensive and too high to be termed a bench and may, in some schemas, be 
considered an inset floodplain - for the purposes of this paper such distinctions are largely semantic, our central concern being the quantity of flat lying surfaces available for suspended sediments to be deposited upon. Table 1 summarises for each of the LiDAR surveyed areas upstream catchment area $\left(\mathrm{km}^{2}\right)$, the extent of in-channel depositional surfaces (ha) and the associated length of channel $(\mathrm{m})$. In the major channels, in-channel depositional surface area per metre of channel ranges from 10 to $485 \mathrm{~m}^{2}$ with an average of $128 \mathrm{~m}^{2}$ and a standard deviation of $103 \mathrm{~m}^{2}$ (Fig. 5A). In the minor channels the range is from 1 to $367 \mathrm{~m}^{2}$ with an average of $71 \mathrm{~m}^{2}$ and a standard deviation of $72 \mathrm{~m}^{2}$ (Fig. 5B). Fig. 6 illustrates the variety of distribution forms displayed through the catchment as well as examples of in-channel deposits as they appear in LiDAR imagery (Fig. 6D-F). Multimodality is clearest in the channels of the middle reaches of the catchment (e.g. LiDAR blocks 5, 10, 12 and 13), whilst lower reaches (LiDAR blocks 2, 25 and 32) see more subdued, unimodal distributions indicating a single low bench between the water surface and the floodplain.

\subsection{Stratigraphy, age and aggradation rate}

Bench stratigraphy varied from almost massive fine to medium sands (KPWN5), to well delineated sequences of decimetre thick units of sand and mud interpreted as being flood couplets (West Normanby; Battle Camp Crossing; Kalpowar; Carrolls Crossing). The West Normanby Bench has accumulated sediment over the last 60 years (See Table 2 for full list of OSL dates) as a series of discrete units of sand and mud at an average rate of $31 \mathrm{~mm} \mathrm{yr}^{-1}$ (Fig. 7). At Battle Camp Crossing, the couplet structure is not as pronounced, but still recognisable (Fig. 8). Here the bench has aggraded at an average rate of $20 \mathrm{~mm} \mathrm{yr}^{-1}$ over the last $\sim 160$ years, with a decline in average rate from $32 \mathrm{~mm} \mathrm{yr}^{-1}$ prior to $0.095 \pm 0.010 \mathrm{ka}$ to $12 \mathrm{~mm} \mathrm{yr}^{-1}$ thereafter. It is possible that deposition at this site ceased approximately 70 years ago based on extrapolation of the trend between 320 and $110 \mathrm{~cm}$ to the surface. The presence of established vegetation including apparently mature trees having girths $>1 \mathrm{~m}$ at the surface supports this interpretation; however, the gradual deposition of material amidst the vegetation cover cannot be ruled out. The bench at KPWN5 provided two ages which indicate a consistent aggradation rate of $2.3 \mathrm{~mm} \mathrm{yr}^{-1}$ for the last $\sim 650$ years (Fig. 9), whilst the Kalpowar Bench has been accumulating over the last 180 years at approximately $11.1 \mathrm{~mm} \mathrm{yr}^{-1}$, possibly slightly slower over the last $\sim 60$ years (Fig. 10). The Kalpowar bench shows evidence of recent erosion (Fig. 10D), such that the surface of the bench has been recently lowered by about 50-100 cm in places. Prior to this stripping, likely to have occurred in the last few years based on the presence of only fines in the infill; i.e. no large events have occurred in the period since the stripping to lay down sand sheets across the bench, aggradation rates at this site would have been measured at a reasonably constant $13 \mathrm{~mm} \mathrm{yr}^{-1}$. The higher surface at Kalpowar, some 1.5 metres above the bench has accumulated $>2 m$ over the last three thousand years (see Section 4.4 ), with the aggradation rate accelerating from $\sim 0.4 \mathrm{~mm} \mathrm{yr}^{-1}$ between $\sim 3 \mathrm{ka}$ and $\sim 1 \mathrm{ka}$ to $\sim 1 \mathrm{~mm}$ averaged over the last $\sim 1 \mathrm{ka}$.

The bench at Carrolls Crossing near Laura on the Laura River is very similar to the west Normanby bench, having multiple decimetre thick units of predominantly sand that have accumulated rapidly ( $\sim 32 \mathrm{~mm} \mathrm{yr}^{-1}$ ) over the last $\sim 60$ years, including the deposition of three discrete $\sim 10 \mathrm{~cm}$ thick units laid down in the last five or so years (Fig. 11). There is an age discontinuity between 210 and $310 \mathrm{~cm}$, possibly indicating the depth of the last stripping event. Interbedded sands and gravels underlying the high floodplain surface at a depth of $1.5 \mathrm{~m}$ date to $21.6 \pm 2.2 \mathrm{ka}$ indicating that the high floodplain was active well into the Pleistocene. The timing and cause of subsequent channel contraction / entrenchment remains to be investigated. Soil formation within the top $\sim 30 \mathrm{~cm}$ of the high surface has obliterated any sedimentary features; however, its finer texture suggests that some intermittent deposition still occurs here, albeit very slowly.

The internal structure of the upper few metres of the inset floodplain at KPWN is revealed in an alluvial gully cutting through the inset floodplain and high floodplain (see Fig. 12). Three OSL samples collected from medium sands reveal that the inset floodplain was emplaced during the middle Holocene, aggrading to within $50 \mathrm{~cm}$ of the present surface. Very diffuse boundaries and a lack of further chronology above this in the profile prevent us from being precise in our estimate of contemporary aggradation rate. However, assuming the diffuse boundary at $\sim 50 \mathrm{~cm}$ is 
evidence of the onset of vertical aggradation during inundation (and not just some artefact of soil formation processes) than we can calculate a maximum possible aggradation rate of $\sim 0.09 \mathrm{~mm} \mathrm{yr}^{-1}$. If we take the diffuse boundary at $\sim 30 \mathrm{~cm}$ depth, and the finer grained sedimentology between 0 and $30 \mathrm{~cm}$ as indicating the onset of fine grain deposition under the influence of contemporary floodwaters, than the calculated aggradation rate falls to $\sim 0.05 \mathrm{~mm} \mathrm{yr}^{-1}$. Regardless of the precise value, we can be confident that it is very much lower than that occurring on the bench lower in the cross section. The internal age structure of the high floodplain is evident in the walls of the same gully complex as that cutting into the inset floodplain. Approximately $12 \mathrm{~m}$ of exposure shows that this floodplain was built through the Late Pleistocene, with approximately $10 \mathrm{~m}$ of medium to coarse sands laid down between $33 \pm 4.5$ and $16.4 \pm 2.6 \mathrm{ka}$, with the upper two metres dating to $8.76 \pm 1.27 \mathrm{ka}$. In contrast to the inset floodplain, no fine material or stratigraphic boundaries are visible near the surface, suggesting abandonment under the current hydrological regime.

\subsection{Relationship between height above thalweg and aggradation rate}

The East Normanby site (Fig. 13) consists of a stepped scroll bar sequence which forms a series of surfaces at different heights relative to the channel thalweg, each with its own inundation frequency. It is possible that these are contractionary depositional features indicative of a change in flow regime over the last several thousand years, or, alternatively, simply related to the slow easterly migration of the channel, or a combination thereof. Regardless of the precise driver(s) behind the construction of these scrolls, their relative elevation provides an opportunity to observe the effect of declining inundation frequency on aggradation rate. The lowermost unit consists of a $2 \mathrm{~m}$ thick sand bar attached to the inside bend, that has accumulated in the last few years, possibly even in the last year, given the complete lack of vegetation either at the surface or throughout the profile. A large sandy, vegetated scroll bar, running more or less concentric with the channel line, exists $3 \mathrm{~m}$ higher up the bank and $\sim 35 \mathrm{~m}$ distal to the assurveyed waterline. This unit has been accreting over the last three- to four-hundred years. Below $\sim 100 \mathrm{~cm}$ depth (and near 300 years ago) $180 \mathrm{~cm}$ accumulated within the 100 years encompassed by the uncertainty bounds on the three lowermost OSL ages, giving a minimum average accumulation rate of $18 \mathrm{~mm} \mathrm{yr}^{-1}$. The uppermost $\sim 100 \mathrm{~cm}$ (assuming the date at $60 \mathrm{~cm}$ is from a single age unit with lower boundary at $\sim 100 \mathrm{~cm}$ ) has accumulated at a rate of $10 \mathrm{~mm} \mathrm{yr}^{-1}$. At a further $40 \mathrm{~m}$ distal to the channel, is an older, higher scroll bar, similarly made of fine sand. Between $\sim 1.8$ and $\sim 1.1 \mathrm{ka}$, this unit accumulated sediment at a rate of approximately $1.3 \mathrm{~mm} \mathrm{yr}^{-1}$, with the uppermost $70 \mathrm{~cm}$ accumulating at an average rate of $0.7 \mathrm{~mm} \mathrm{yr}^{-1}$. On the uppermost scroll bar observed at East Normanby, an augur hole revealed $2 \mathrm{~m}$ of fine sand, accumulating since $5.5 \mathrm{ka}$ at an average rate of $0.36 \mathrm{~mm} \mathrm{yr}^{-1}$. Clearly, there is a negative correlation between height above the thalweg and aggradation rate. This relationship is discussed further in Section 5.1 below, forming the basis of a sediment budget incorporating in-channel deposition.

\subsection{Floodplain aggradation}

Stratigraphy and age structure for all floodplain sites are summarised in Fig. 14. Bizant Gully shows evidence of a dramatic decline in aggradation rate. About 3500 years ago, approximately $1 \mathrm{~m}$ of accretion occurred, at a rate sufficiently rapid that it occurred within the period bracketed by the uncertainty bounds on the dates ( 700 years). This implies that the minimum aggradation rate during this period was $\sim 1.4 \mathrm{~mm} \mathrm{yr}^{-1}$. Extrapolating this modelled age depth relationship up profile indicates that aggradation to the present surface level was complete $\sim 2500$ years ago. Some incipient soil development at this location is consistent with this interpretation, though a very low aggradation rate averaging $0.3 \mathrm{~mm} \mathrm{yr}^{-1}$ cannot be excluded altogether. An aggradation rate of $0.8 \mathrm{~mm} \mathrm{yr}^{-1}$ is observable since $\sim 2200$ years ago at Bizant River. The age structure at IBA 16 (a flood monitoring site approximately midway between Saltwater $\mathrm{Ck}$ and the Morehead River, and $\sim 20 \mathrm{~km}$ south of the mouth of the North Kennedy River), though somewhat uncertain due to a multimodal single grain $D_{\mathrm{e}}$ distribution at depth $50 \mathrm{~cm}$, clearly indicates an extremely low deposition rate. Of all the modes displayed in the $D_{\mathrm{e}}$ distribution for the uppermost sample, it is not clear which, if any, represent the actual deposition age for that depth. It is likely that pedoturbation processes have resulted in the downward admixture of younger deposits, with this likely to have occurred during surface stability. The reported 
age for $50 \mathrm{~cm}$ depth $(2.53 \pm 0.31 \mathrm{ka})$ should therefore be considered a minimum age, and the associated aggradation rate $\left(\sim 0.2 \mathrm{~mm} \mathrm{yr}^{-1}\right)$ a maximum.

There are three phases of aggradation observable at a small pocket of floodplain at Normanby Station (NSVF1). At about 3000 years ago almost a metre of sandy material accumulated within the time encompassed by the uncertainty bounds of the two bracketing ages, giving a minimum aggradation rate of $0.6 \mathrm{~mm} \mathrm{yr}^{-1}$. In the 2000 years following this another $\sim 1 \mathrm{~m}$ of slightly finer material accumulated at a rate of $\sim 0.3 \mathrm{~mm} \mathrm{yr}{ }^{-1}$. The uppermost $50 \mathrm{~cm}$ of fine silty sand accumulated sometime in the last 1000 years, at a rate of $0.5 \mathrm{~mm} \mathrm{yr}-1$. Between $\sim 10$ and $\sim 4.8$ ka the floodplain beside the Morehead River (MHRFP) accumulated sediment at $0.09 \mathrm{~mm} \mathrm{yr}^{-1}$, with this approximately doubling since then to $0.2 \mathrm{~mm} \mathrm{yr}^{-1}$. Below $\sim 160 \mathrm{~cm}$ depth the Morehead River has cut into mottled sediments dating from $31.7 \pm 3.2 \mathrm{ka}$, with this unit likely representative of sediments to be found at depth more broadly, being similar in appearance and likely age of the material below the upper floodplain unit at IBA $16 \sim 9 \mathrm{~km}$ to the north west.

In contrast to the very slow aggradation rates observed for other proximal floodplain sites, the uppermost $180 \mathrm{~cm}$ of the floodplain beside the Normanby River (NRFP) aggraded comparatively rapidly around 600 years ago, that is, about $1 \mathrm{~m}$ within the 240 years encompassed by the combined uncertainty bands, or $\sim 4.2 \mathrm{~mm} \mathrm{yr}^{-1}$. Extrapolating this to the obvious stratigraphic break at $10 \mathrm{~cm}$ indicates it likely formed after 400 years ago, giving a minimum aggradation rate of $0.25 \mathrm{~mm} \mathrm{yr}^{-1}$. The uppermost $\sim 10 \mathrm{~cm}$ may overlap with European settlement. However, even if it was deposited entirely within this period, then its deposition rate $\left(\sim 1 \mathrm{~mm} \mathrm{yr}^{-1}\right)$ would still be a quarter of that occurring in the previous 500 years.

\subsection{Coastal floodplains}

Sites NKCP1 and NKCP2 are on the coastal plain near the mouth of the North Kennedy River. At NKCP1 the uppermost two samples provide ages which overlap within uncertainties (Fig. 15). In consideration of the uncertainties on the ages, the minimum aggradation rate between these two sample depths is $2.4 \mathrm{~mm} \mathrm{yr}^{-1}$. Extrapolating this age depth model to the surface suggests deposition ceased $\sim 500$ years ago. At NKCP2 (4 km NE of NKCP1), the uppermost two samples likewise overlap within uncertainties, giving a minimum aggradation rate of 2.1 $\mathrm{mm} \mathrm{yr}^{-1}$. Extrapolated to the surface, this age depth model provides a deposition cessation date $\sim 570$ years ago. Sometime after this, the unit began to be eroded as evidenced by the extensive scarp into which the exposure was cut, probably by a process of parallel retreat under the influence of wave action, coupled with some base-level change to the tidal channels that traverse these intertidal plains. Changes in progradation rate, caused by a decline in sediment export though the Holocene from the catchment (Chappell, 1982), may have also been instrumental in initiating erosion of the coastal plain.

\section{Discussion}

\subsection{Sediment budget}

Table 3 summarises aggradation rates as measured at all sites. We have determined five bench accretion rates (31, 20, 2.3, 13 and $32 \mathrm{~mm} \mathrm{yr}^{-1}$ ) which together provide an average bench accretion rate of $19.7 \mathrm{~mm} \mathrm{yr}^{-1}$. This value is similar to other bench accretion rates measured in northern and southeastern Australia (Rustomji and Pietsch, 2007; Wasson et al., 2010; Hughes et al., 2010). From the nine estimates of aggradation rates on floodplains, an average of $0.33 \mathrm{~mm} \mathrm{yr}^{-1}$ is calculated - just $2 \%$ of that observed on the benches. For the single inset floodplain site investigated, we determined an aggradation rate of $0.09 \mathrm{~mm} \mathrm{yr}^{-1}$, i.e. intermediate between that of the bench and that of the upper floodplain $\left(\sim 0 \mathrm{~mm} \mathrm{yr}^{-1}\right)$. The coastal plain sites likely have effectively zero contemporary aggradation rates, with the plain dominated by pedestals and scarps, remnants of a previous surface- deposited at higher relative sea level or under conditions of higher sediment export as hypothesised by Chappell (1982). In fact unpublished tracing data collected by the authors strongly supports the hypothesis that the coastal plain is a significant source of material to $\mathrm{PCB}$, rather than being an en route sediment sink. From these data it is clear that the fastest rates of 
aggradation within the Normanby catchment are occurring below the floodplain on depositional surfaces of varying ages. The importance of this within the catchment wide sediment budget therefore depends on the extent of these features and the variety of aggradation rates occurring within this zone. The results obtained at the east Normanby site (Fig. 13), limited though they are, provide us with a basis for developing a model of aggradation rate of benches and inset floodplains relative to their surface height above, and distance from, the thalweg, that can be used to estimate in-channel aggradation rates throughout the catchment. Fig. 13D clearly shows that aggradation rates drop markedly, from near 1000 to $0.36 \mathrm{~mm} \mathrm{yr}^{-1}$ as the elevation above the thalweg increases. These data highlight aggradation rates differing by several orders of magnitude from the lowest bench to that surface just below the floodplain. This observation is more or less repeated at the three other locations where multiple aggradation sections have been examined within a single cross section. At KPWN for example, where the inset floodplain is intermediate in height between the bench and floodplain, it has a depositional rate approximately one order of magnitude less than the bench below and one order of magnitude greater than the floodplain above. At Kalpower, the bench $\sim 4 \mathrm{~m}$ below the upper surface has an aggradation rate approximately 10 times greater. Similarly, at Carrolls crossing, the high surface $5 \mathrm{~m}$ above the sampled bench is underlain by interbedded sand and gravel dating to $21.6 \pm 2.2 \mathrm{ka}$, indicating this surface is effectively abandoned. Hence, even though the higher surfaces often occupy greater area, the total volume of sediment deposited on the lower surfaces may be greater than that on the higher surfaces when measured over management timescales (decades - centuries). To test this within a sediment budget we have used the various aggradation values at the East Normanby cross section to develop a general model and then apply this across the catchment.

Although at first glance Fig. 13D might be interpreted as indicating aggradation of in-channel surfaces varies across four orders of magnitude, we believe this would be an overestimate of the range experienced at most sites. The large range measured at this site is partly a function of the $\sim 1000 \mathrm{~mm} \mathrm{yr}^{-1}$ value measured on the point bar, a feature clearly related to bed material transport and likely to be a transient feature equivalent to the similar scale, more or less linear bars of sand and gravel found throughout the catchment. We therefore consider the range encompassed by the three scroll bars (i.e. $~ 2$ orders of magnitude) more likely to represent the range found throughout the catchment. This accords with our measurements of aggradation elsewhere, which show that 20-30 mm $\mathrm{yr}^{-1}$ is the maximum aggradation rate for features sitting relatively close to the thalweg but which have residence times of many decades at least, whilst the lowest floodplain aggradation rates provide a useful minimum value (i.e. $\sim 0.2 \mathrm{~mm}$ $\left.\mathrm{yr}^{-1}\right)$. Although the average floodplain deposition rate $\left(0.39 \mathrm{~mm} \mathrm{yr}-\mathrm{rable}^{-1}\right)$ is somewhat higher than this, it includes sites that are leveed, hence the aggradation rates on the very proximal floodplain likely exceed the rates possible on the highest within-channel surfaces (and indeed, the distal parts of the floodplain). Furthermore, this average value is also heavily influenced by the high aggradation rate measured on the Kalpowar Upper Surface, which is likely somewhat lower in elevation than the expansive floodplain. In summary, we interpret these results as indicating that a range in aggradation rates is likely to be experienced at any one site, depending on elevation above, and distance from, the thalweg, with this range likely to stretch over two orders of magnitude, from $\sim 20 \mathrm{~mm} \mathrm{yr}^{-1}$

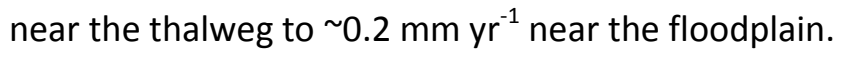

With an understanding of in channel depositional feature distribution and aggradation at a number of sites, it is now

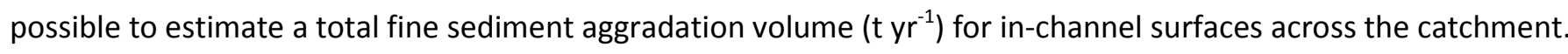
Cogniscant of the inherent variability between sites, we have taken a parsimonious approach to estimating total aggradation for each LiDAR block and thence the catchment as a whole. The aggradation rate per unit length of

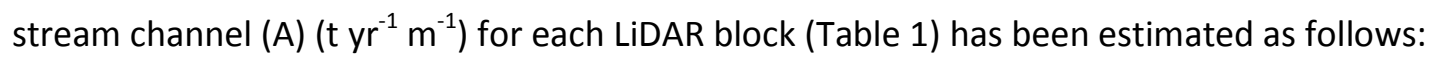

$$
A=\frac{\sum_{x_{1}}^{x_{n}} a_{x} b_{x} \rho p}{l}
$$

where $x$ is the elevation of bench (or inset floodplain) $\mathrm{n}$ above bench 1 (the lowest surface), $a_{x}$ is the area of bench (or inset floodplain) at elevation $x\left(\mathrm{~m}^{2}\right), b_{x}$ is the aggradation rate on the surface at elevation $x\left(\mathrm{~m} \mathrm{yr}^{-1}\right), \rho$ the estimated sediment density $\left(1.8 \mathrm{t} \mathrm{m}^{-3}\right), \mathrm{p}$ is the proportion silt/clay $(0.26$ - see particle size analysis results in Table 3$)$ 
and $l$ is the length of thalweg in the LiDAR block $(\mathrm{m})$. We have assumed on the basis of the current measurements that the aggradation rates on the 'bench' surfaces decrease exponentially with height above the thalweg:

$$
b_{x}=k e^{-\beta x}
$$

where $k$ is the deposition rate that would be expected at bench 1 and $\beta$ is the decay constant. The limits on this exponential function are set by observing the spread between the peak corresponding to the thalweg and the peak corresponding to the floodplain in the plots of the sort shown in Figs. 3E, 4D and 6A-C, with the upper aggradation rate for the lowermost benches at all sites set to $20 \mathrm{~mm} \mathrm{yr}^{-1}$ and the lower set to $0.2 \mathrm{~mm} \mathrm{yr}^{-1}$ for the highest within channel surfaces (see Eq. 1 and Fig. 16). Therefore

$$
\begin{aligned}
& 0.02=k e^{-\beta . x_{1}} \\
& 0.0002=k e^{-\beta . x_{n}}
\end{aligned}
$$

Such that:

$$
\beta=\frac{\ln 100}{\left(x_{n}-x_{1}\right)}
$$

Finally, these values are used to estimate annual storages of silt/clay per $\mathrm{km}$ in channel reaches not included in the LiDAR coverage. For this purpose we have found it convenient to distinguish 'major' channels from 'minor' channels, using the AHGF mapping, along with the catchment scale model of channel geometry developed by Brooks et al (2013). For the 'minor' channels we have established a relationship between the modelled width of each channel reach and aggradation volume (Fig. 17A):

$$
\text { AFS (annual fines storage; tonnes } \mathrm{km}^{-1} \mathrm{yr}^{-1} \text { ) }=2.3 \times \text { width }-37
$$

Using this relationship we have assigned an aggradation volume to all $18,966 \mathrm{~km}$ of minor stream channel within the Normanby Catchment. For the major channels that we have observed within our LiDAR blocks, no significant relationship was found between the aggradation volume determined and any of the modelled stream geometry variables (Fig. 17B). We have accordingly simply extrapolated or interpolated from the channel reaches within the LiDAR blocks to all the other reaches of 'major' channel, based on spatial proximity of each channel reach to the LiDAR blocks. Where major channels have no LiDAR coverage from which to extrapolate or interpolate from, we have assigned them the average AFS value obtained from all LiDAR blocks (Fig. 18). The total annual in-channel storage of fine sediment across the catchment, calculated in the first instance as the sum of the estimated storage in each reach is 388 ktonnes in the major channels and 1205 ktonnes in the minor channels. For comparison, the value determined from the major channels using Eq. (7) is 465 ktonnes.

It should be noted that the rates per linear $m$ of thalweg are used for calculating the in-channel deposition below the high floodplain within each reach. 'Floodplain' deposition has been calculated in an entirely different way (see Brooks et al 2013) referencing time and frequency of inundation, and sediment concentrations in floodwaters. Hence our comparisons between in-channel depositional surfaces and floodplains as discussed below are based on the relative scale of the totals calculated to have been deposited in each of these zones.

The storage figures calculated do not, however, account for differences in sediment supply and presence/absence of competing depositional zones as material is routed through the catchment. Refinements to these figures that take into consideration spatial variations in sediment supply and inundation frequency through the catchment require the construction of a sediment budget, such as that described by Brooks et al (2013). Using detailed measurements of erosion sources throughout the Normanby catchment, in combination with a new spatially and temporally explicit 
catchment sediment model, they estimate an average annual input of fine sediment from all sources of 3.09 Mtonnes, including 370 ktonnes from alluvial gully erosion, which likely has been greatly accelerated since the introduction of cattle. Incorporating the results of the present study into this routing model shows that, of the 3.09 $\mathrm{Mt} \mathrm{yr}^{-1}$ input, $2.3 \mathrm{Mt}(75 \%)$ is stored en route to the catchment outlet. Of this $2.3 \mathrm{Mt}, 1.2 \mathrm{Mt}(53 \%)$ can be accounted for by storage on within channel benches and inset floodplains, with the remainder stored on the upper floodplain. Clearly in-channel deposition needs to be accounted for when developing sediment budgets for catchments like the Normanby.

\subsection{Land-use change response}

The lowest KPWN bench yielded ages of several hundred years at 1-1.5 m, with no evidence of increased aggradation rates post AD 1870 (Fig. 9). In contrast, the other four benches (and the upper metre or so of scroll 1 at East Normanby) all show evidence of establishment and/or greatly increased aggradation rates in the last 140 years (Figs. 7, 8, 9, 10, 11, and 13). Although somewhat obscured by the level of precision of some dates particularly the lowermost dates at Kalpowar and Battle Camp Crossing, it is clear that the period of European settlement has been coincident with a period of significant bench building. Three possible scenarios can be envisaged to explain these results:

1. The types of benches investigated generally have a lifespan of a century or two, before they are destabilised and removed by intermittent erosive flows with recurrence intervals more or less matching the lifespan of the benches. Hence the dates we have collected simply reflect the lifetime of the benches under the natural sediment and hydrological regime.

2. The benches (excepting the KPWN bench) are the result of occupation of accommodation space created by a general channel expansion episode associated with a period of increasingly erosive flows occurring around the period of settlement. Since then a diminished flow regime has seen channel contraction. No change in sediment regime is necessary.

3. The building of the benches is a response to the increased sediment production in the catchment following European settlement. Although bench building is not unique to this period (as evidenced by the bench at KPWN) the predominance of this time period within the sampled benches suggests that this form of channel response became increasingly prevalent as a result of increased sediment production from the catchment.

Of these three scenarios, we believe the third to be the most likely. Scenario 1 would see some proportion of the benches destroyed each year regardless of flow regime, whereas we see no evidence (save some minor stripping of parts of the Kalpowar bench) of bench erosion in the catchment. This is supported by recent field data (Brooks et al., 2014a) that demonstrates these benches support vigorous riparian vegetation with high root densities throughout their banks up to 10000 roots $\mathrm{m}^{-2}$ on the bank surface. Scenario 2 is more difficult to dismiss. On the one hand, runoff reconstructions of coastal catchments in Queensland have shown clearly that there has been no change in the amount of runoff impacting the GBR since European settlement (Lough, 2007), though the hydrological variability appears to have increased in the 20th century. In detail, however, reconstructions from coral cores collected several hundred kilometres south of the Normanby (the 'R3' reconstruction of Lough, 2011) appear to show the period immediately following settlement (1890-1900) as being of above average annual rainfall and runoff. Could this have been a period of regionally widespread channel expansion, including the Normanby catchment? Though possible, for this scenario to be accepted, it would be necessary to conclude that more or less equivalent periods that followed (1910-1920; 1950-1960; 1970-1980) have had no equivalent broad scale channel expansion response. Rather than being unusual, the coral record for the decade following settlement is interpreted as part of a persistent shift towards increased runoff and increased variability that began around 1860.

Scenario 3 is supported by the coincidence in timing (i.e. within the period following settlement) of the onset of rapid bench aggradation at four out of the five sites. Though this is more or less coincident with the hydrological shift 
identified by Lough $(2007 ; 2011)$ we would expect that these changes would, in the absence of an increased sediment supply, result in a predominance of bench destruction over bench creation. Furthermore our ongoing studies into the timing and scale of gully erosion in the Normanby Catchment (Brooks et al, 2013) clearly indicate that gully erosion has been a significantly enhanced source of sediment since settlement and that the volume of material produced has been of a scale similar in order of magnitude to that which has been stored in the benches and other depositional surfaces below the floodplain. Brooks et al (2013) provide a figure of 370 ktonnes as a best estimate of the increase in annual sediment export since settlement due to accelerated alluvial gully erosion. So, although we cannot definitively state which, if any, of these three scenarios is the most likely, we consider the weight of evidence to be with scenario 3.

We note that at two sites (Carrolls Crossing and Kalpowar) the aggradation rates actually decline through the period of European settlement. This could, however, be a function of the gradual increase in surface elevation over time, whereby, using the $\sim 2$ orders of magnitude variation described above as a guide, a $1 \mathrm{~m}$ increase in elevation from 3 to $4 \mathrm{~m}$ above the thalweg of a $10 \mathrm{~m}$ deep channel, would result in a $32 \%$ decline in aggradation rate. This effect alone could account for the observed declines in bench aggradation at these sites.

None of the floodplain sites shows evidence of accelerated deposition following European settlement, though it is arguable whether or not our technique is sufficiently precise to allow observation of anything less than a catastrophic increase in aggradation rate of the type seen in some settings in southeastern Australia. At the very least, however, we can rule out the presence of any units of 'post settlement alluvium (PSA)' (sensu Wasson et al., 1998) on the highest floodplain. Although we would not expect such units to be extensive across the whole expanse of the floodplain, it is noteworthy that they do not exist even as narrow strips built as channel levees - the majority of our floodplain sampling sites being directly beside contemporary channels. It should be noted, however, that the floodplains where PSA is typically observed tend to be fairly confined floodplains in the mid-upper reaches of much smaller catchments in SE Australia. Hence the extensive areas of the Normanby floodplains would tend to mitigate against the preservation of obvious PSA.

\subsection{Management implications}

Deposition on surfaces below the high floodplain has been a significant part of the fine (i.e. $<63 \mu \mathrm{m}$ ) sediment

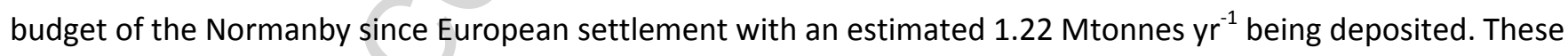
surfaces therefore have played an important role in reducing output of fine sediments from the catchment to PCB and thence the GBR. Any management activity such as heavy stocking and displacement of native riparian vegetation via weed infestation that potentially destabilises these surfaces could see reintroduction of these previously quarantined sediments back into the sediment stream. At the very least it is clear from this study that a sediment budget of any comparable large catchment must include the deposition of suspended sediment on benches and other surfaces below the floodplain. Management decisions, especially those regarding the targeting of sediment reduction activities, need to be made with the benefit of sediment budget models which incorporate the role of inchannel depositional surfaces.

\subsection{Further refinements}

This study provides a first estimate of the likely contribution of storage on within-channel surfaces to the fine sediment budget. Despite the large body of data assembled here, there are some clear gaps that have become apparent through the course of the study that will require addressing to make further refinements to future models. Firstly, additional examples of the relationship between aggradation rate and elevation above the thalweg are required to confirm that the form described (i.e. varying over approximately 2 orders of magnitude) is widespread. While the other geochronological data we have collected are consistent with this model, further examples of single sites with systematically collected aggradation rates would be preferable. Ideally, it would be useful to separate sites according to broad riverscape type, for example separating channels with floodplains bound by valley sides from 
channels existing in the open floodplain area of the lower catchment. Secondly, our fieldwork program was conducted prior to our close examination of the LiDAR data which has shown that, for the minor channels at least, inset floodplains as distinct from the narrow linear features traditional described as benches provide a large proportion of the available flat lying, below high-floodplain, surfaces for aggradation. Unfortunately our field program included only one example of these features (KPWN-3), so their general age structure remains unknown. However, they are intermediate in elevation above the thalweg between sites we have sampled examples of, and we have no reason to suspect that elevation above the thalweg is not the prime determinate of aggradation rate. Finally, we have applied a constant \% fines value when converting annual aggradation rates on in-channel surfaces to stored volume of fine sediment. This may not be correct. It could be expected, for example, that the proportion of sand in deposits would decrease with elevation above the bed. However, from the sparse data we have for withinchannel deposits, no dramatic increase in proportion of fines is observed with elevation above the thalweg.

In consideration of the likely impact (positive or negative) of the above described refinements, we consider that any such further refinements to our model would result in the calculated proportion of fine sediment being stored within the channel increasing. Hence, despite the presence of these significant data gaps, we consider our conclusions around the importance of within channel depositional surfaces to the fine sediment budget of the Normanby catchment to stand.

\section{Conclusion}

This study has shown that within channel sediment stores play an important role in the sediment budget of the Normanby catchment, with at least $53 \%$ of all fine sediment $(<63 \mu \mathrm{m})$ storage within the catchment occurring within the channel. Additionally, in-channel storages have ages extending from many decades to many centuries, indicating that regardless of the precise mechanism of system resetting or re-equilibrating, these sites play an important role in mediating sediment export over timescales of significance to catchment management.

\section{Acknowledgements}

This study was jointly funded by the Australian Government Caring for our Country Reef Rescue program, and Griffith University. We are grateful to Ted Lee, the Laura Rangers, Thomas Brooks-Wallace, Jo Hoyle, Jenny Spencer, Jason Carroll and Bungie Scott for assistance with fieldwork.

\section{References}

Aitken, M.J., 1998. An introduction to optical dating. Oxford University Press, Oxford.

Australian Bureau of Meteorology, 2013. Australian Hydrological Geospatial Fabric (Geofabric). http://www.bom.gov.au/water/geofabric/

Bartley, R., Bainbridge, Z.T., Lewis, S.E., Kroon, F.J., Wilkinson, S.N., Brodie, J.E. and Silburn, D.M., 2014. Relating sediment impacts on coral reefs to watershed sources, processes and management: A review. Science of the Total Environment, 468-469C: 1138-1153, http://dx.doi.org/10.1016/j.scitotenv.2013.09.030.

Brodie, J., McKergow, L.A., Prosser, I.P., Furnas, M., Hughes, A.O., Hunter, H., 2003. Sources of Sediment and Nutrient Exports to the Great Barrier Reef World Heritage Area, p. 192. ACTFR Report 03/11.

Brooks, A. P., Brierley, G. J., 1997. Geomorphic responses of lower Bega River to catchment disturbance, 1851-1926. Geomorphology, 18, 291-304.

Brooks, A. P., Brierley, G. J., 2000. The role of European disturbance in the metamorphosis of lower Bega River. IN Brizga, S. O.,Finlayson, B. L. (Eds.) River Management: The Australasian Experience. London, John Wiley and Sons. 
Brooks, A. P., Spencer, J., Olley, J., Pietsch, T., Borombovits, D., Curwen, G., Shellberg, J., Howley, C., Gleeson, A., Simon, A., Bankhead, N., Klimetz, D., Eslami-Endargoli, L., Bourgeault, A., 2013. An Empirically-based Sediment Budget for the Normanby Basin: Sediment Sources, Sinks, and Drivers on the Cape York Savannah. Griffith University, $506 p p$.

Brooks, A.P., Olley, J., Iwashita, F., Spencer, J., McMahon, J., Curwen, G., Saxton., N. and S. Gibson. (2014a). Final Report to Qld State Government, Department of Science Information Technology Innovation and the Arts, Griffith University, pp 76.

Brooks, A.P., Borombovits, D., Spencer, J., Pietsch, T., Olley, J., (2014b). Measured hillslope erosion rates in the wetdry tropics of Cape York, northern Australia Part 1: A low cost sediment trap for measuring hillslope erosion in remote areas - trap design and evaluation Catena, v122:1-17

Brooks, A.P., Spencer, J., Borombovits, D., Pietsch, T., Olley, J., (2014c). Measured hillslope erosion rates in the wetdry tropics of Cape York, northern Australia: Part 2, RUSLE-based modeling significantly over-predicts hillslope sediment production Catena v122:42-53.

Chappell, J., 1982. Sea level and sediments: some feature of the context of coastal archeological sites in tropics.Archaeol. Oceania 17, 69-78.

Croke, J., Todd, P., Thompson, C., Watson, F., Denham, R. and Khanal, G., 2013. The use of multi temporal LiDAR to assess basin-scale erosion and deposition following the catastrophic January 2011 Lockyer flood, SE Queensland, Australia. Geomorphology, 184: 111-126, 10.1016/j.geomorph.2012.11.023.

Dietrich, W., Dunne, T., 1978. Sediment budget for a small catchment in mountainous terrain. Zeitschrift Fur Geomorphologie, Suppl. Bnd. 29, pp 191-206.

Dunne, T., Leopold, L.B., 1978. Water in Environmental Planning. W.H. Freeman, San Francisco.

Eriksson, M., Olley, J., Kilham, D., Pietsch, T., Wasson, R., 2006. Aggradation and incision since the very late Pleistocene in the Naas River, south-eastern Australia. Geomorphology, 81 (no. 1-2): 66-88.

Erskine, W.D., Warner, R.F., 1988. Geomorphic effects of alternating flood and drought-dominated regimes on NSW coastal rivers. In: Warner, R.F. (Ed.), Fluvial Geomorphology of Australia. Academic Press, Sydney, pp. $223-244$.

Erskine, W., Chalmers, A., Keene, A., Cheetham, M., Bush, R., 2009. Role of a rheophyte in bench development on a sand-bed river in southeast Australia. Earth Surface Processes and Landforms 34, 941-953.

Erskine, W., Keene, A., Bush, R., Cheetham, M., Chalmers, A., 2012. Influence of riparian vegetation on channel widening and subsequent contraction on a sand-bed stream since European settlement: Widden Brook, Australia. Geomorphology 147-148, 102-114.

Fabricius, K., De'ath, G., McCook, L., Turak, E., Williams, D.McB., (2005) Changes in algal, coral and fish assemblages along water quality gradients on the inshore Great Barrier Reef. Marine Pollution Bulletin, 51 (1-4), pp. $384-398$.

Finlayson, B.L., McMahon, T.A., 1988. Australia vs. the world: a comparative analysis of stream-flow characteristics. In: Warner, R.F. (Ed.), Fluvial Geomorphology of Australia. Academic Press, Sydney, pp. 17-40. Ch.2.

Galbraith. R. F., Laslett, G. M., 1993. Statistical models for mixed fission track ages. Radiation Measurements 21, 459470. 
Page 16 of 43

Galbraith, R.F., Roberts, R.G., Laslett, G.M., Yoshida, H., Olley, J.M., 1999. Optical dating of single and multiple grains of quartz from Jinmium rock shelter, northern Australia, part 1, Experimental design and statistical models.

Archaeometry 41, 339-364.

Hughes, A.O., Croke, J.C., Pietsch, T.J., Olley, J.M., 2010. Changes in the rates of floodplain and in-channel bench accretion in response to catchment disturbance, central Queensland, Australia. Geomorphology, 114(3): 338-347.

Hoyle, J., Brooks, A.P., Brierley, G.J., Fryirs, K., Lander, J. (2008). Spatial variability in the timing, nature and extent of channel response to typical human disturbance along the Upper Hunter River, New South Wales, Australia. Earth Surface Processes and Landforms 33(6) pp. $868-889$.

Hoyle, J., Brooks, A.P., Spencer, J. (2012). Modelling reach-scale variability in sediment mobility: An approach for within-reach prioritization of river rehabilitation works. River Research and Applications, 28(5), 609-629.

Jacobs, Z., Duller, G.A.T., Wintle, A.G., 2006. Interpretation of single grain De distributions and calculation of De. Radiation Measurements 41, 264-277.

Kemp, J., 2004. Flood channel morphology of a quiet river, the Lachlan downstream from Cowra, southeastern Australia. Geomorphology, 60(1-2), 171-190.

Lough, J.M., 2007. Tropical river flow and rainfall reconstructions from coral luminescence: Great Barrier Reef, Australia. Paleoceanography, 22 (2), art. no. PA2218.

Lough, J.M., 2011. Great Barrier Reef coral luminescence reveals rainfall variability over northeastern Australia since the 17 th century. Paleoceanography, 26 (2), art. no. PA2201.

McKergow, L.A., Prosser, I.P., Hughes, A.O., Brodie, J., 2005. Sources of sediment to the Great Barrier Reef World Heritage Area. Marine Pollution Bulletin 51, 200-111.

Mejdahl, V., 1979. Thermoluminescence dating: beta-dose attenuation in quartz grains. Archaeometry 21, 61-72.

Murray, A.S., Marten, R., Johnston, A., Martin, P., 1987. Analysis for naturally occurring radionuclide's at environmental concentrations by gamma spectrometry. Journal of Radio Analytical and Nuclear Chemistry 115, 263288.

Nanson, G.C., Erskine, W.D., 1988. Episodic changes of channels and floodplains on coastal rivers in New South Wales. In: Warner, R.F. (Ed.), Fluvial Geomorphology of Australia. Academic Press, Sydney, pp. $201-221$ (Chapter 10).

Nathan, R.P., Thomas, P.J., Jain, M., Murray, A.S., Rhodes, E.J., 2003. Environmental dose rate heterogeneity of beta radiation and its implications for luminescence dating: Monte Carlo modelling and experimental validation. Radiation Measurements, 37 (4-5), pp. 305-313.

Olley, J.M., Pietsch, T., Roberts, R.G., 2004. Optical dating of Holocene sediments from a variety of geomorphic setting using single grains of quartz. Geomorphology, 60: 337-358.

Olley, J., Brooks, A., Spencer, J., Pietsch, T., Borombovits, D., 2013. Subsoil erosion dominates the supply of fine sediment to rivers draining into Princess Charlotte Bay, Australia. Journal of Environmental Radioactivity 124, 121129.

Olley, J., Brooks, A., Spencer, J., Pietsch, T., Borombovits, D., Howley., C., Curwen., G. (in prep) Geochemistry and provenance of sediments from Princess Charlotte Bay, Northern Great Barrier Reef, Australia. 
Peel, M.C., McMahon, T.A., Finlayson, B.L., 2004. Continental differences in the variability of annual runoff-update and reassessment. Journal of Hydrology 295, 185-197.

Pietsch, T.J., 2009. Optically stimulated luminescence dating of young ( $<500$ years old) sediments: Testing estimates of burial dose. Quaternary Geochronology 4, 406-422.

Prosser, I.P., Winchester, S.J., 1996. History and processes of gully initiation and development in eastern Australia. Z. Geomorphol. Suppl. 105, 91- 109.

Prosser, I.P., Chappell, J., Gillespie, R., 1994. Holocene valley aggradation and gully erosion in headwater catchments, southeastern highlands of Australia. Earth Surface Processes and Landforms. 19, 465-480.

Prosser, I.P., Rustomji, P., Young, W.J., Moran, C.J., Hughes, A.O., 2001. Constructing River Basin Sediment Budgets for the National Land andWater Resources Audit. CSIRO Land and Water, Technical Report 15/01.

Prescott, J.R., Hutton, J.T., 1994. Cosmic ray contributions to dose rates for luminescence and ESR dating: large depths and long-term time variations. Radiation Measurements 23, 497-500.

Roberts, R.G., Galbraith, R.F., Yoshida, H., Laslett, G.M., Olley, J.M., 2000. Distinguishing dose populations in sediment mixtures: a test of single-grain optical dating procedures using mixtures of laboratory-dosed quartz. Radiation Measurements 32, 459-465.

Rustomji, P., 2008. A Comparison of Holocene and Historical Channel Change along the Macdonald River, Australia. Geographical Research 46, 99-110.

Rustomji, P., Pietsch, T., 2007. Alluvial sedimentation rates from southeastern Australia indicate post-European settlement landscape recovery. Geomorphology 90(1-2): 73-90.

Rustomji, P., Bennet, N., Chiew, F., 2009. Flood variability east of Australia's Great Dividing Range. Journal of Hydrology 374, 196-208.

Scott, A., 2001. Water erosion in the Murray-Darling Basin: Learning from the past. CSIRO Land and Water Technical Report, 43/01.

Shellberg, J., Brooks, A., Spencer, J., 2010. Land-use change from indigenous management to cattle grazing initiates the gullying of alluvial soils in northern Australia, Soil Solutions for a Changing World, 19th World Congress of Soil Science, 1 - 6 August 2010. Brisbane, Australia, pp. 59-62.

Shellberg, J.G., Brooks, A.P., Rose, C.W., 2013. Sediment production and yield from an alluvial gully in northern Queensland, Australia. Earth Surface Processes and Landforms, DOI: 10.1002/esp.3414.

http://onlinelibrary.wiley.com/doi/10.1002/esp.3414/abstract

Stokes, S., Ingram, S., Aitken, M.J., Sirocko, F., Anderson, R., Leuschner, D., 2003. Alternative chronologies for late Quaternary (Last Interglacial - Holocene) deep-sea sediment via optical dating of silt-size quartz. Quaternary Science Reviews 22, 925-941.

Thompson, C. and Croke, J., 2013. Geomorphic effects, flood power, and channel competence of a catastrophic flood in confined and unconfined reaches of the upper Lockyer valley, southeast Queensland, Australia. Geomorphology, 197: 156-169, 10.1016/j.geomorph.2013.05.006.

Thoms, M.C., Olley, J.M., 2004.The stratigraphy, mode of deposition and age of inset floodplains on the BarwonDarling River, Australia. in (eds. Golosov, V. Walling, D.E. and Wallbrink, P.J.) Sediment transfer through fluvial systems, IAHS Publ. no 288 , 316-325. 
Page 18 of 43

van Niekerk, A.W., Heritage, G.L., Broadhurst, L.W., and Moon, B.P. 1999. Bedrock anastomosing channel systems: morphology and dynamics in the Sabie River, Mpumalanga Province, South Africa. In Varieties Fluvial Form. Edited by A.J. Miller and A. Gupta. John Wiley \& Sons, Chichester, U.K. pp. 33-51.

Vietz, G.J., Rutherfurd, I.D., Stewardson, M.J., 2004. Not all benches are created equal: proposing and field testing an in-channel river bench classification. In: Rutherfurd,I., Wiszniewski, I., Askey-Doran, M., Glazik, R. (Eds.), 4th Aust. Stream Mngmt. Conf. Department of Primary Industries, Water and Environment, Launceston, Tasmania, pp. 629635.

Vietz, G.J., Rutherfurd, I.D., Stewardson, M.J., Finlayson, B., 2012. Hydrodynamics and sedimentology of concave benches in a lowland river. Geomorphology 147-148, 86-101.

Walling, D.E., Russell, M.A., Hodgkinson, R.A., Zhang, Y., 2002. Establishing sediment budgets for two small lowland agricultural catchments in the UK. Catena 47, 323-353.

Wasson, R.J., Mazari, R.K, Starr, B.J., Clifton, G., 1998. The recent history of erosion and sedimentation on the Southern Tablelands of southeastern Australia: implications for soil conservation. Geomorphology. 24, 291-381

Wasson, R. J., Furlonger, L., Parry, D., Pietsch, T., Valentine, E., Williams, D., 2010. Sediment sources and channel dynamics, Daly River, northern Australia. Geomorphology, 114(3), 161-174. 


\section{Figure Captions}

Fig. 1. Map of the Normanby catchment showing major channels and location of LiDAR blocks (grey boxes) and sampling sites (closed circles). Site labels are a: NKCP2; b: NKCP1; c: NRFP; d: Bizant R; e: Bizant Gully; f: IBA16; g: MRFP; h: Kalpowar; i: Battlecamp Crossing; j: NSVF1; k: KPWN; I: Carrolls Crossing; m: East Normanby; n: West Normanby. The valley transect approximately delineates the sequence of riverscapes down valley, with reaches A-D described in text and Fig. 2 . The grey shading is mapped alluvium, the stippling shows the coastal plain. Inset shows position of catchment within Queensland.

Fig. 2. Riverscapes of the Normanby catchment. Representative LiDAR block extracts for each of the valley transect reaches identified in Fig. 1 are shown on the left, with black lines showing location of cross-sections. Extracts are from block 7 (Reach A upper), block 5 (Reach A lower), block 14 (Reach B), block 2 (Reach C) and data collected along a swath parallel to the coastline at the southern end of Princess Charlotte Bay, but not further analysed (Reach D). Schematic stratigraphic cross-sections accompany each LiDAR extract on the right (below in the case of reach D). Reach $A$ is described with two examples, each showing macro-channels entrenched into Late Pleistocene floodplain material ('FP'), with Early-Mid Holocene floodplains ('IFP') inset within the macro-channel along with Late Holocene benches, generally of linear form ('LB') sitting low beside the channel. Reaches B, C and D have more subdued topography with simpler stratigraphy. See Section 2 for details.

Fig. 3. Processing steps used to delineate benches using high resolution LiDAR data, in this case for block 5 , containing sampling sites KPWN1, 3 and 5. A) Extract from the hillshade display of the digital elevation model for block 5 showing manually digitised thalweg in red. B) Slope calculated from the DEM. C) Slope categorisation into flat $\left(<8^{\circ}\right)$ and not flat $\left(>8^{\circ}\right)$, note clear delineation of steep banks, and flat areas of the floodplain and benches within channel. D) Map of bench height (relative to the nearest point of the thalweg - see text) within the buffer that extends on to the high floodplain hundreds of metres from the thalweg. In this way the obvious 'benches' either side of the channel (including the inset floodplain) near KPWN5 are captured. E) frequency histogram of observed 'bench' elevation data for all of block 5 (thick grey line), with peaks associated with the derived water surface and high floodplain indicted. Note the water surface is 'stepped' due to the low point density caused by non-reflective water bodies, hence the spread in this peak is an artefact of the data collection process. The dotted red line provides a probable distribution for the gravel bars observed within the channel, whilst the solid red lines provide probable distributions for distinct benches observed in the field. The thick black line indicates the sub-component of the entire distribution that represents the in channel depositional area, that is, once the water surface, gravel bars and floodplain have been removed.

Fig. 4. Illustration of example output from depositional surface delineation. A) Hillshade extract of LiDAR block 4. B) In-channel deposition areas (solid grey) and floodplain (cross hatched) corresponding to two surfaces. C) Cross section (white line in B). D) Histogram showing the frequency distribution of surface elevation above thalweg; the peaks represent elevation of the main in-channel surfaces and the upper floodplain surface.

Fig. 5. Histogram plots showing the frequency distribution of in-channel depositional area per metre of channel for A) the major channels and B) the minor channels.

Fig. 6. Typical in-channel depositional area distributions found in A) the ephemeral minor channels; B) mid reach major channels; and C) estuarine reach. These are the distributions for Blocks 24, 12 and 32 respectively, with the $y$ axes showing in each case the total flat area within each LiDAR block. D) E) and F) are extracts from blocks 21, 7 and 40 respectively, showing, in grey, examples of areas we classified as 'in-channel', being above the mobile bed (white polygon in each case encompassed by grey) and below the floodplain. Areas within the grey polygons having a slope $<8^{\circ}$ are classified as in-channel depositional areas. D) provides an example of linear features running parallel to the main channel, which approximate the form of 'benches' as defined elsewhere, whereas E) and F) provide examples of features that sit outside traditional definitions - a low inset floodplain and inter-channel islands. Though not of 
traditional bench form, these features nonetheless provide significant storage capacity above the mobile bed but below the floodplain. All maps at same scale, with North to the top of page.

Fig. 7. West Normanby Bench site details. A) Stratigraphy. B) OSL ages and aggradation model. C) topography (hillshaded extract from LiDAR block 4) showing sampling location for the West Normanby Bench. D) Channel cross section through sampling location (black line in C). Dotted line shows location and depth of pit.

Fig. 8. Battle Camp Crossing site details. A) Stratigraphy, B) OSL ages and aggradation model for the Battle Camp Crossing Bench. No cross-sectional or LiDAR data were collected for this site. Symbols are as per legend in Fig. 7A.

Fig. 9. Kingsplains West Normanby site details. A) Site photo and stratigraphic section for KPWN5. Symbols are as per legend in Fig. 7A. B) OSL ages and aggradation model for KPWN5. C) Hillshaded LiDAR image (extract from LiDAR block 5) showing the sampling location (KPWN5) and the associated cross section for the KPWN Bench. Location of sampling locations (KPWN1 and KPWN3) and cross section provided in Fig. 12 also indicated. D) Channel cross section. Dotted line shows location and depth of KPWN5 pit.

Fig. 10. Kalpowar site details. A) Site photo and stratigraphic section for Kalpowar Bench. Symbols are as per legend in Fig. 7A. B) OSL ages and aggradation model for Kalpowar Bench. C) Channel bank cross section for the Kalpowar Bench. Dotted lines show location and depth of pits. D) Nearby evidence for minor bench top stripping, with exposed tree root flares at approximately 50 and $100 \mathrm{~cm}$ above the present surface.

Fig. 11. Carrolls Crossing site details. A) Site photo and stratigraphic section for Carrolls Crossing Bench. Symbols are as per legend in Fig. 7A. B) OSL ages and aggradation model for Carrolls Crossing Bench. C) Bank cross section for the Carrolls Crossing Bench. Dotted line shows location and depth of pit. D) Photo for the Carrolls Crossing Bench, looking downstream along the top of the bench. The toe of the slope to the high surface is just visible in the left of the image.

Fig. 12. Second cross section from LiDAR block 5 (see Fig. 9), intersecting an inset floodplain (KPWN3) and the high floodplain (KPWN1). Dotted lines show locations of KPWN3 pit and KPWN5 exposure. Symbols are as per legend in Fig. 7A.

Fig. 13. East Normanby site details. A) Hillshaded LiDAR image (extract from LiDAR block 4) showing the location of the East Normanby cross section. B) Cross section topography. Dotted lines show locations and depth of sampling pits. C) Stratigraphic sections and age structure of East Normanby scroll array. Symbols are as per legend in Fig. 7A. Age model plots omitted for clarity. D) Relationship between aggradation rate and height above thalweg.

Fig. 14. Stratigraphy and age structure for the floodplain sites.

Fig. 15. Stratigraphy and age structure for sites NKCP1 and NKCP2 on the coastal plain, with upper photo showing aerial view of remnant pedestals (vegetated) and lower photo providing a ground view of the scarps formed at pedestal boundaries. Symbols are as per legend in Fig. 14.

Fig. 16. Schematic representation of application of exponential decay model of aggradation rate vs bench elevation. A) Idealised channel cross-section (solid line) showing mobile bars (grey) and water surface in the bed and two discrete benches (at $\sim 3.5$ and $\sim 7.5 \mathrm{~m}$ ) on the left bank below a high floodplain (at $\sim 13 \mathrm{~m}$ ). The dotted line indicates the flat area frequency distribution that would be produced if this cross-sectional form was universal throughout the area of interest (i.e. the ideal LiDAR block). B) Application of Eqs. (2) to (6), producing a model of aggradation rate for all elevations above the mobile bed but below the high floodplain. The product of the flat area frequency distribution and the aggradation rate model provides the total accumulated sediment volume. With corrections applied for channel length, sediment density and proportion silt/clay as per Eq. (1), we arrive at our total

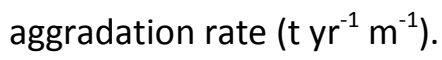


Fig. 17. Relationship between channel width (as modelled by Brooks et al., 2013) and annual storage of fine sediment for A) minor channels and B) major channels. Note the fit (see Eq. 7) illustrated in A) is for widths above 20 $\mathrm{m}$ and excludes the one obvious outlier (shown in grey). For minor channels with widths below $20 \mathrm{~m}$, an annual storage of fine sediment of 5 tonnes $\mathrm{km}^{-1}$ has been used, based on observation of the distribution of values for these smallest channels.

Fig. 18. Map of the Normanby catchment showing the distribution of in-channel storage of fine sediment. The grey shading is mapped alluvium, the stippling shows the coastal plain. 


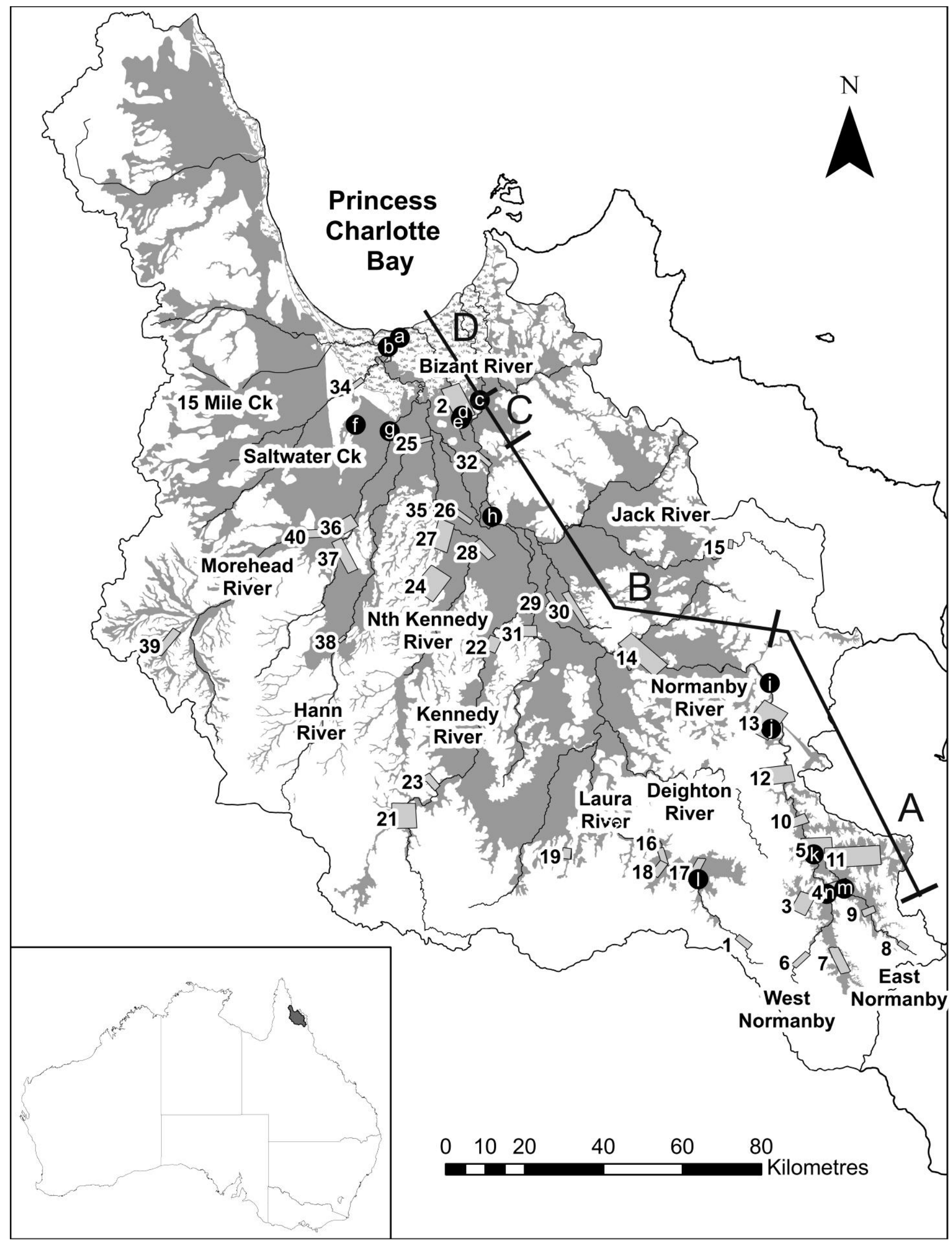

Figure 1 
Page $\mathbf{2 3}$ of $\mathbf{4 3}$

ACCEPTED MANUSCRIPT
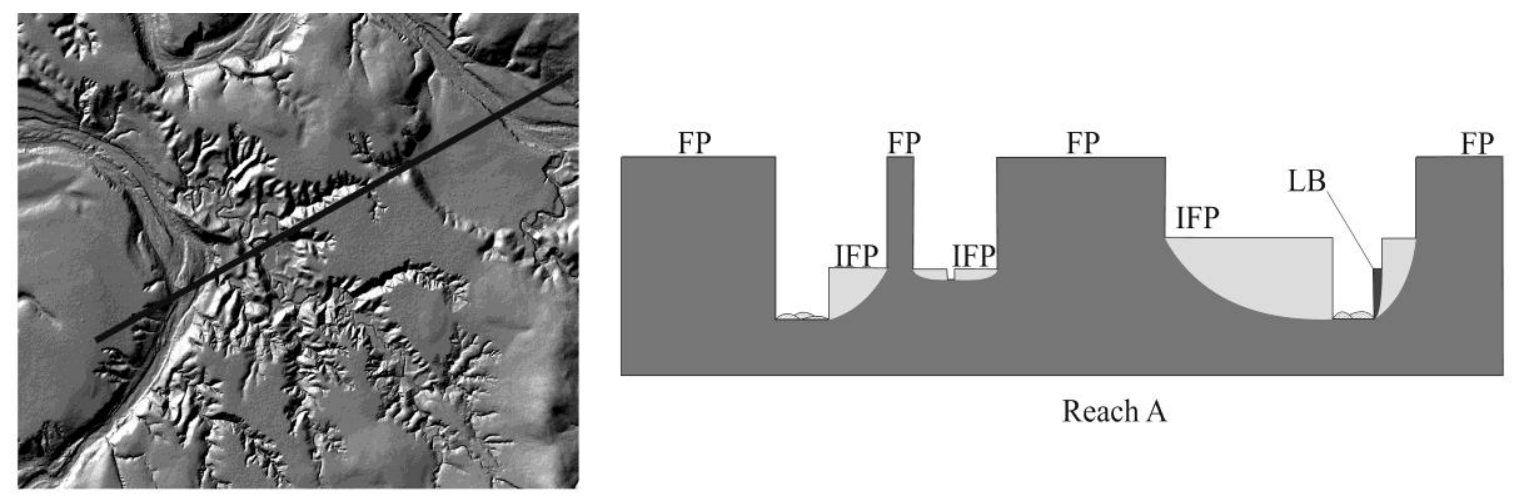

Reach A
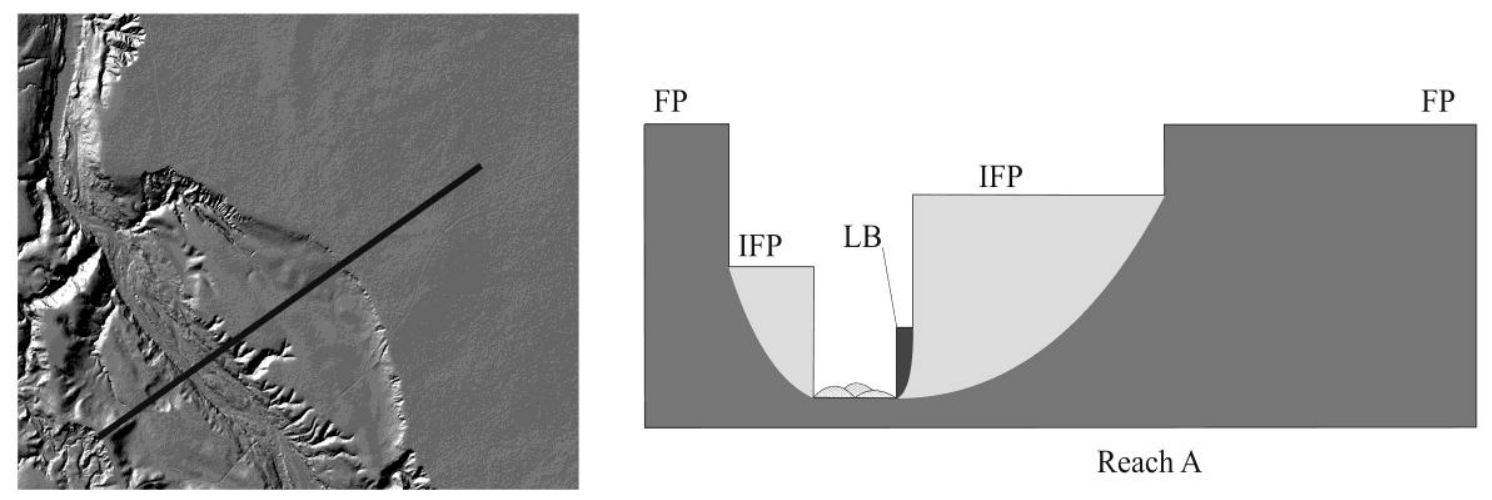

Reach A
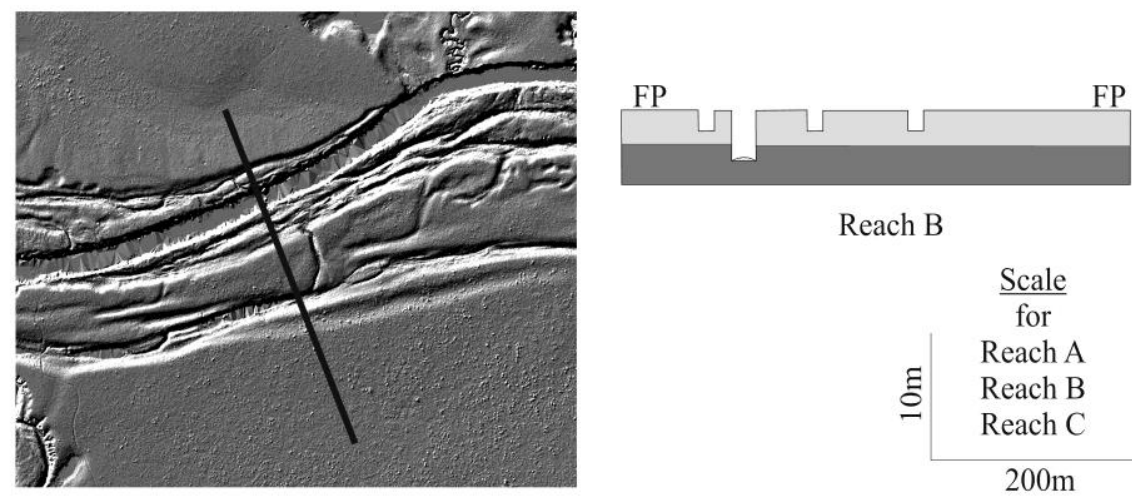

Reach B
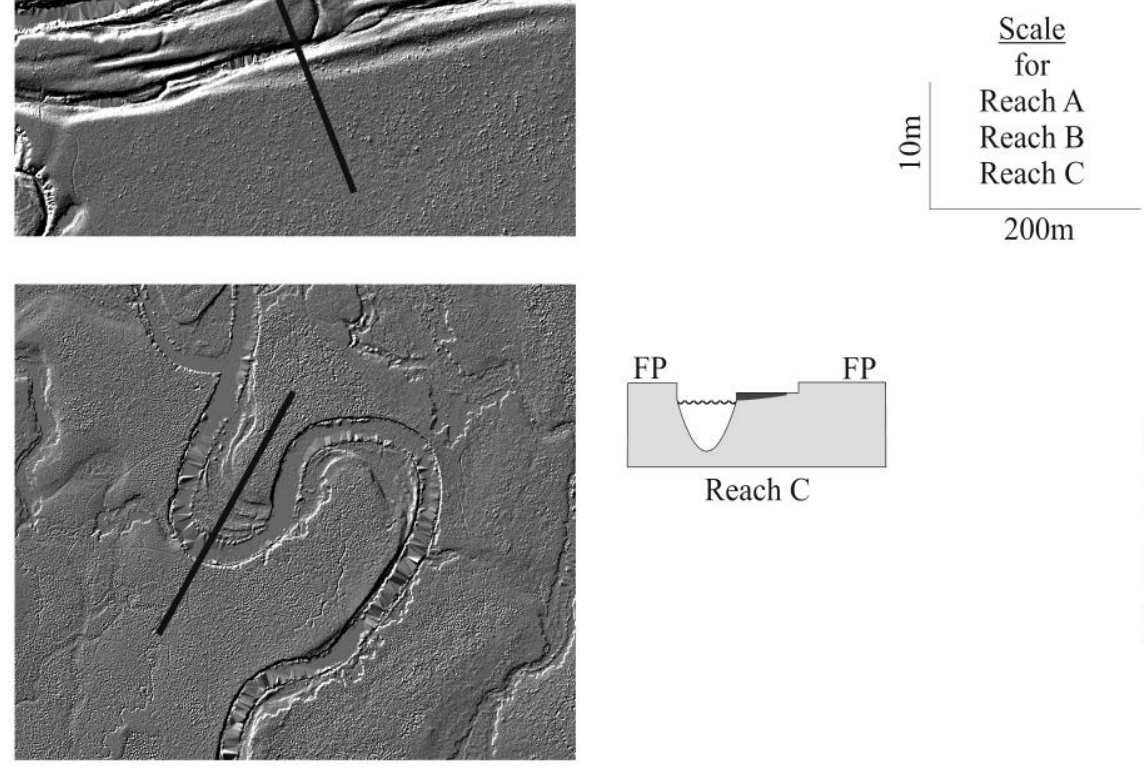

Late Pleistocene

Reach C

Early - Mid Holocene

Late Holocene

$\square \quad$ Contemporary Bedload

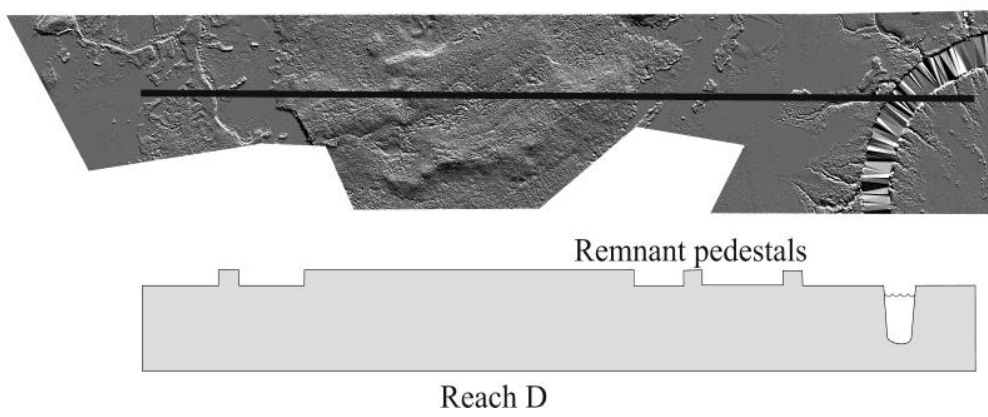

Figure 2 
Page 24 of $\mathbf{4 3}$

ACCEPTED MANUSCRIPT
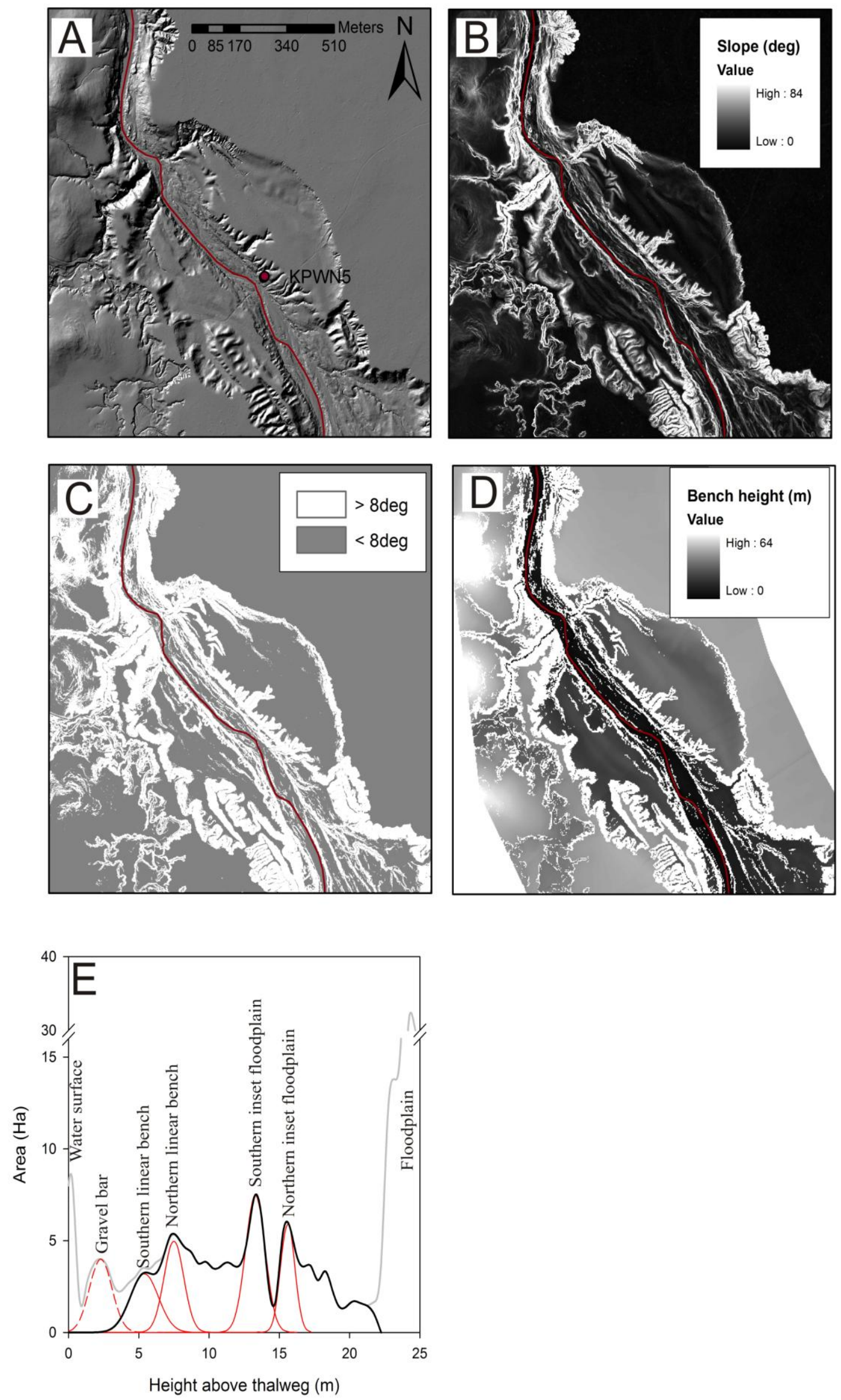

Figure 3 
Page $\mathbf{2 5}$ of $\mathbf{4 3}$
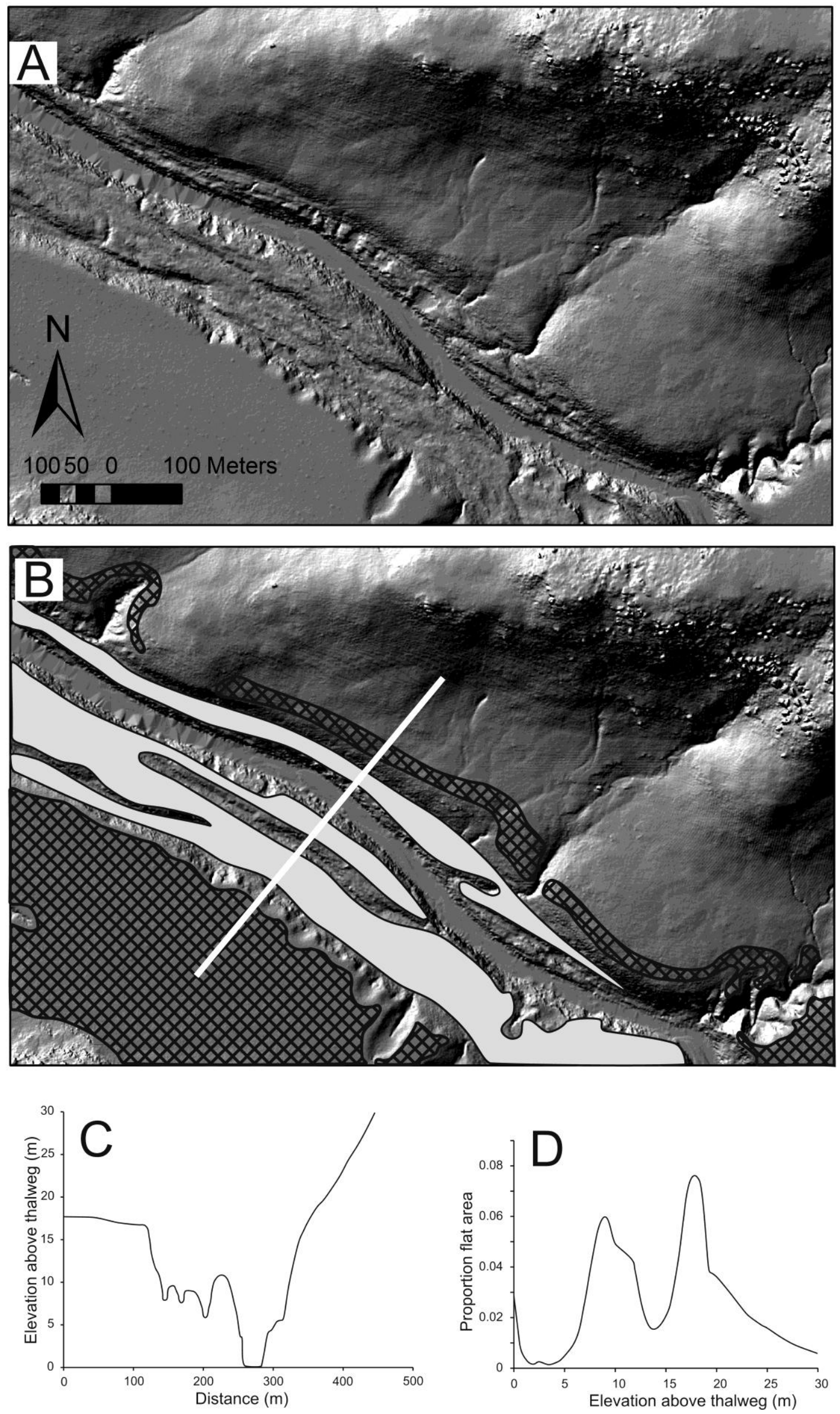

Figure 4 
Page $\mathbf{2 6}$ of $\mathbf{4 3}$

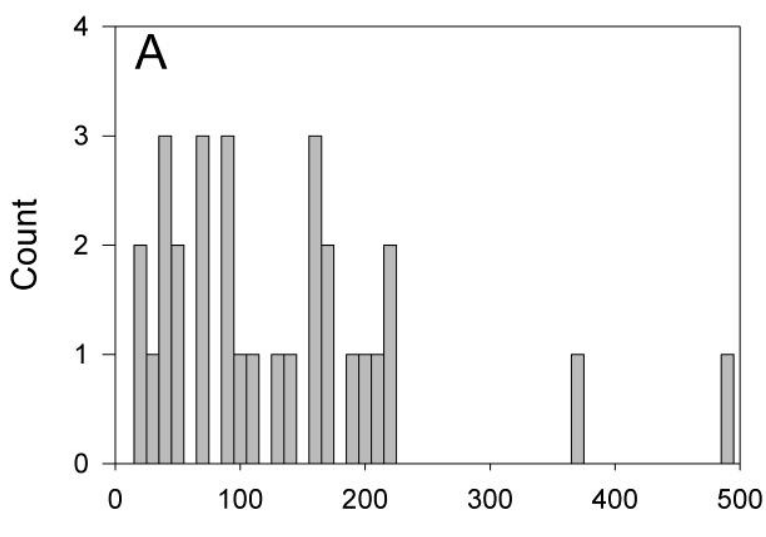

Bench area $\left(\mathrm{m}^{2}\right.$ per linear channel $\left.\mathrm{m}\right)$

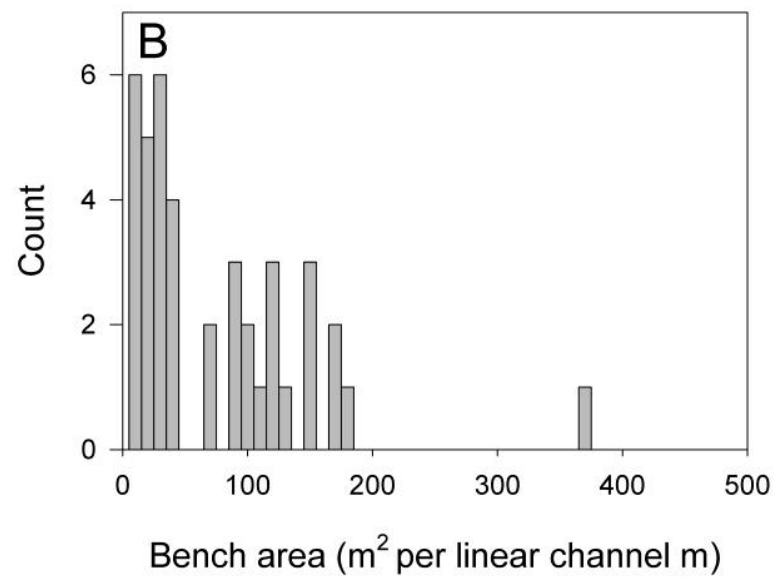

Figure 5 
Page $\mathbf{2 7}$ of $\mathbf{4 3}$

\section{ACCEPTED MANUSCRIPT}
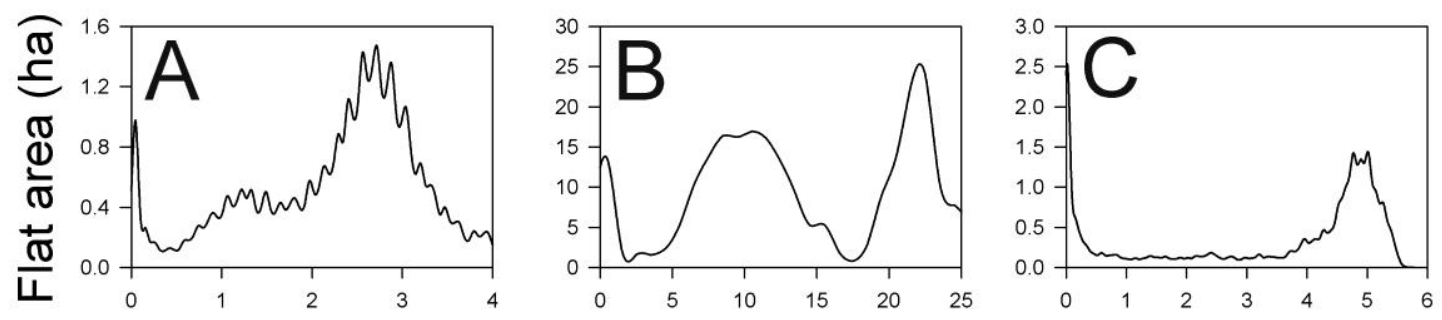

Height above thalweg (m)
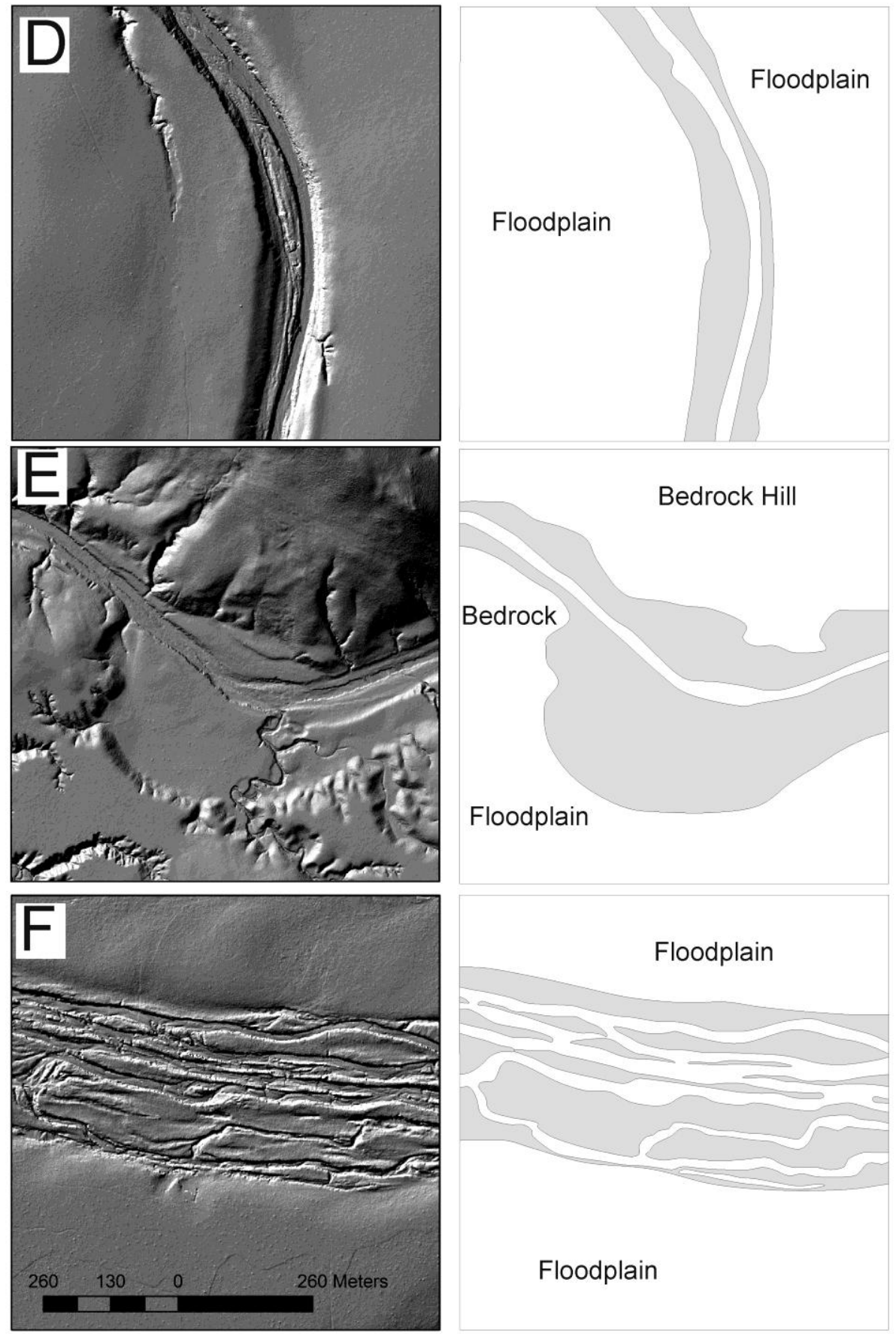

Floodplain

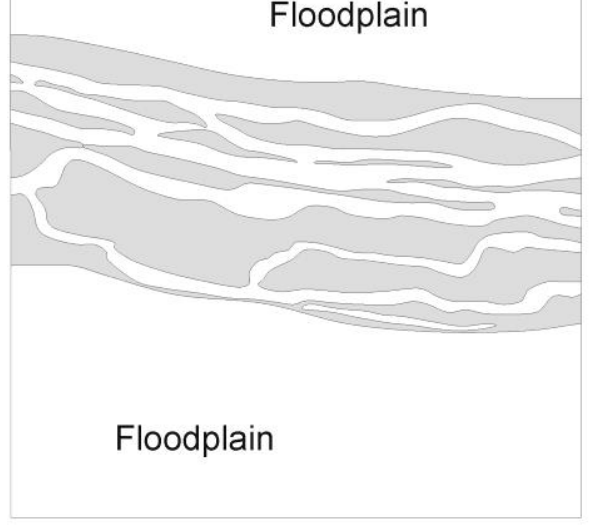

Figure 6 
Page $\mathbf{2 8}$ of $\mathbf{4 3}$

\section{ACCEPTED MANUSCRIPT}

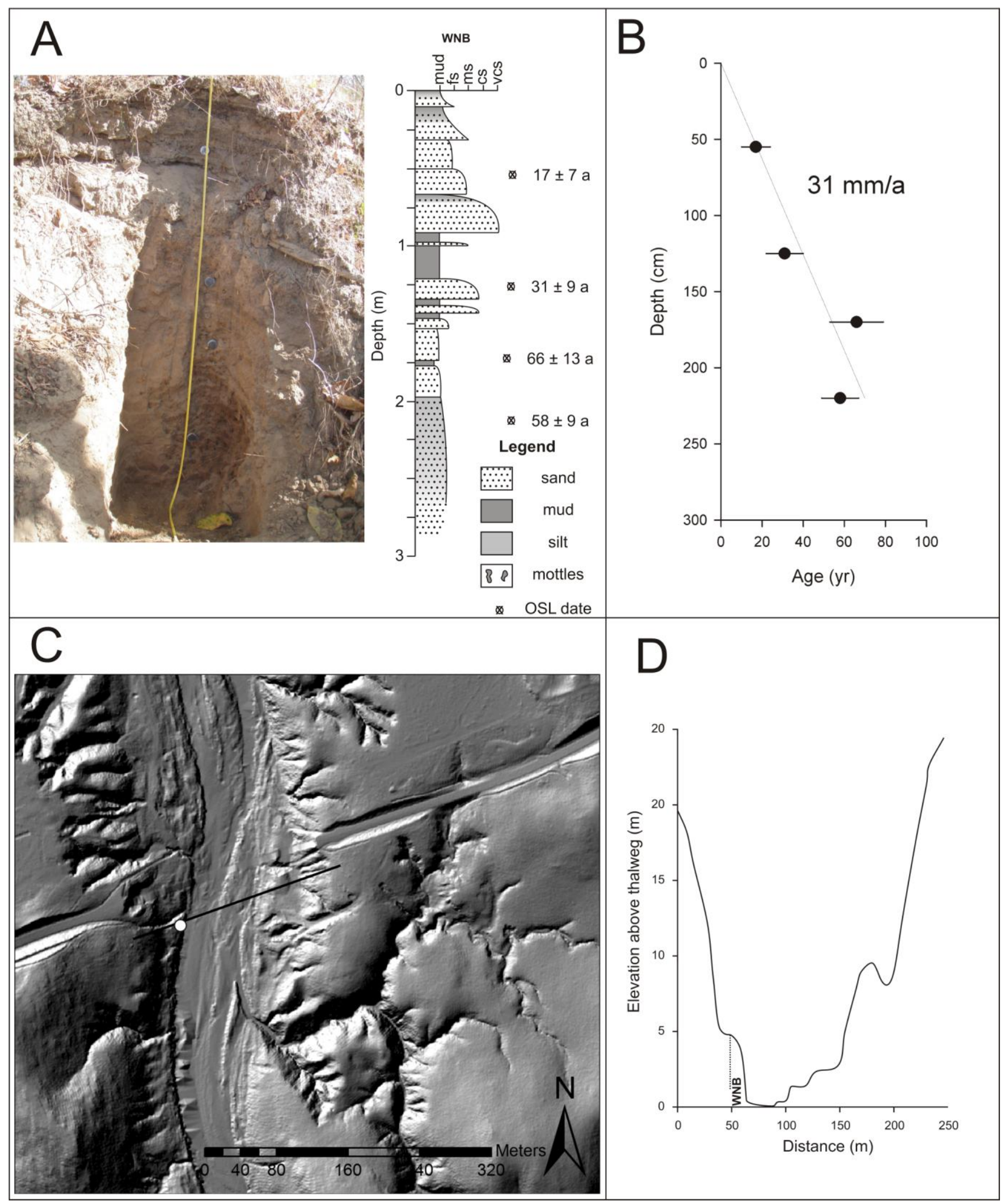

Figure 7 
Page $\mathbf{2 9}$ of $\mathbf{4 3}$

ACCEPTED MANUSCRIPT

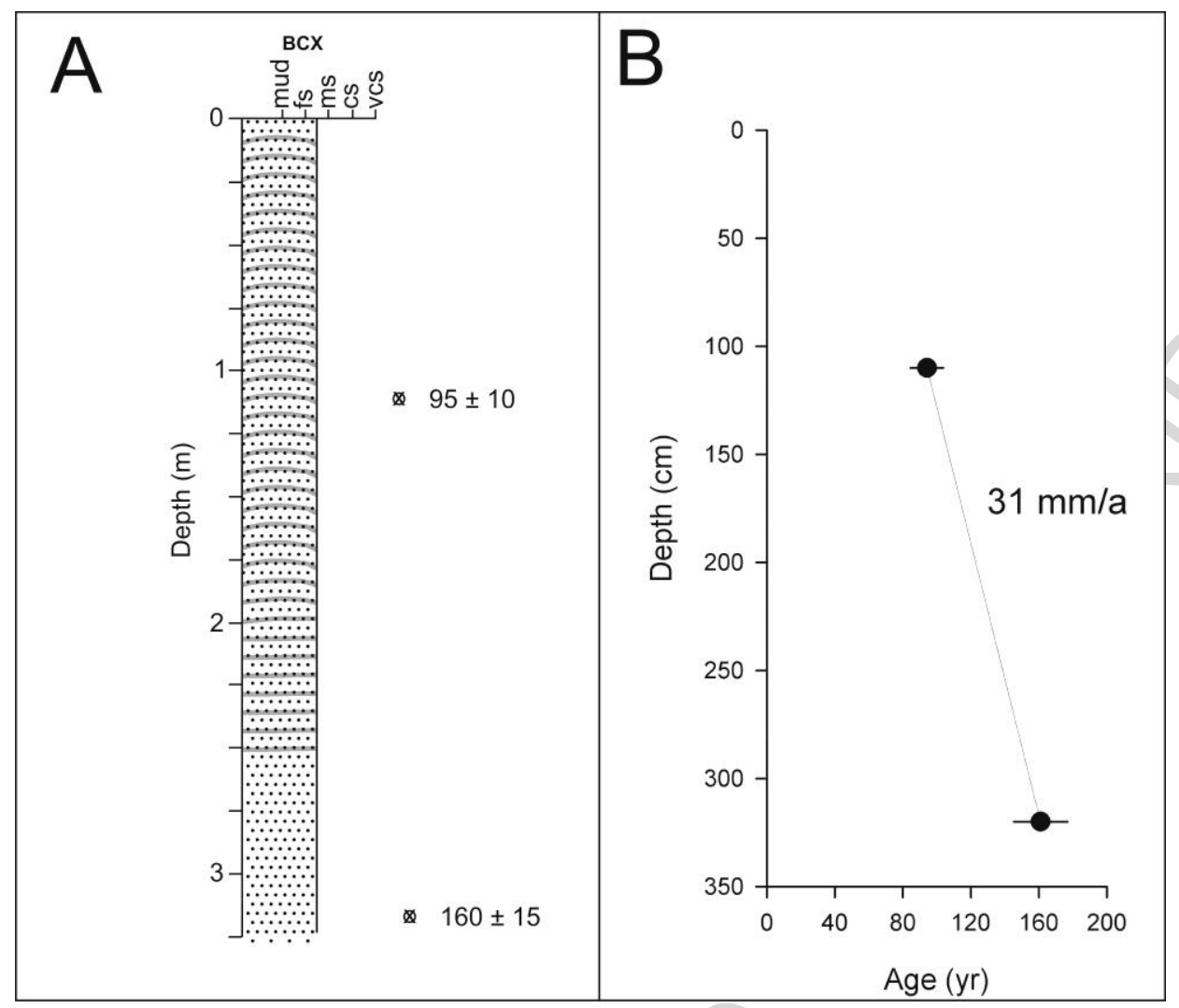

Figure 8 
Page $\mathbf{3 0}$ of $\mathbf{4 3}$

ACCEPTED MANUSCRIPT

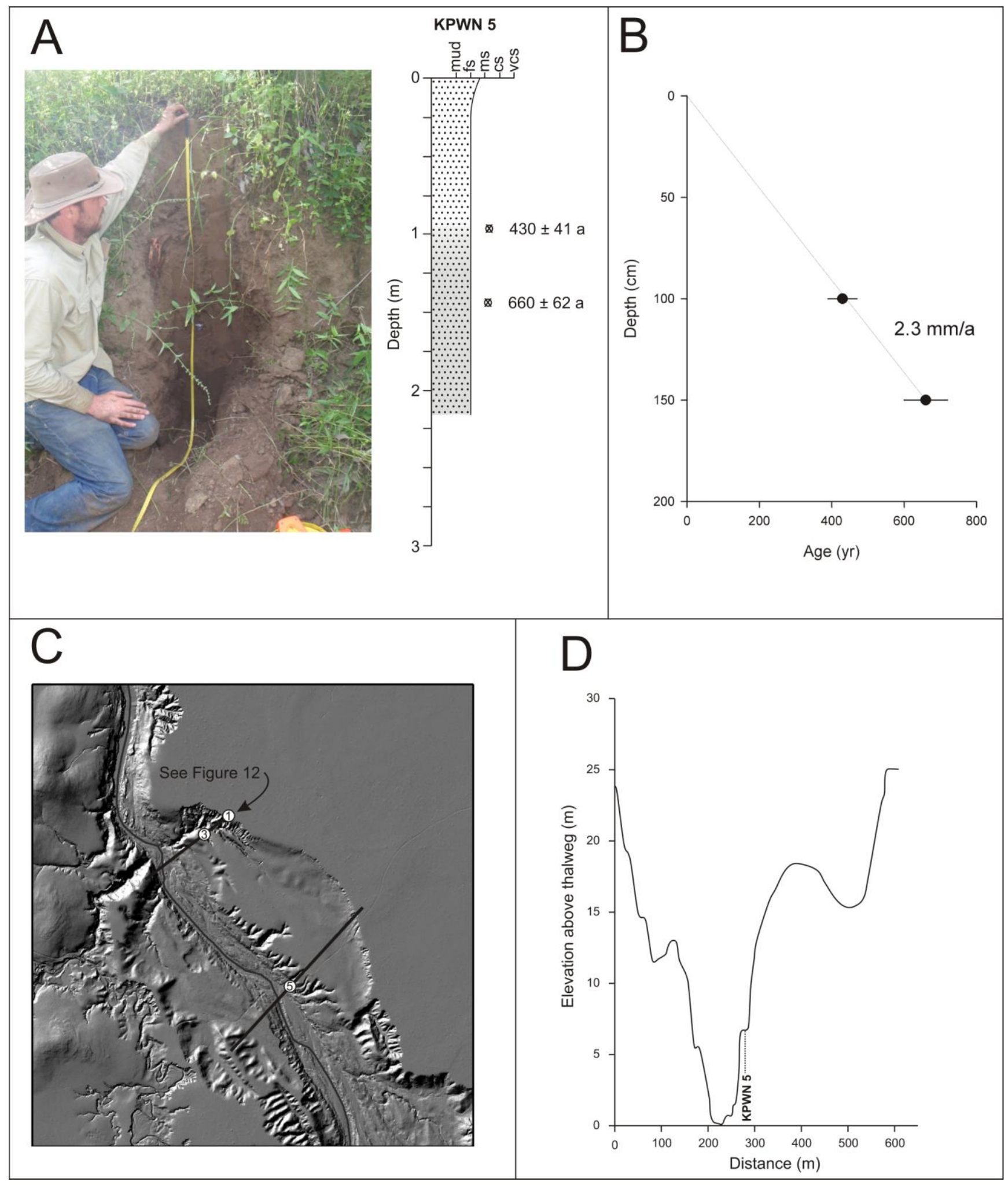

Figure 9 
Page $\mathbf{3 1}$ of $\mathbf{4 3}$

ACCEPTED MANUSCRIPT

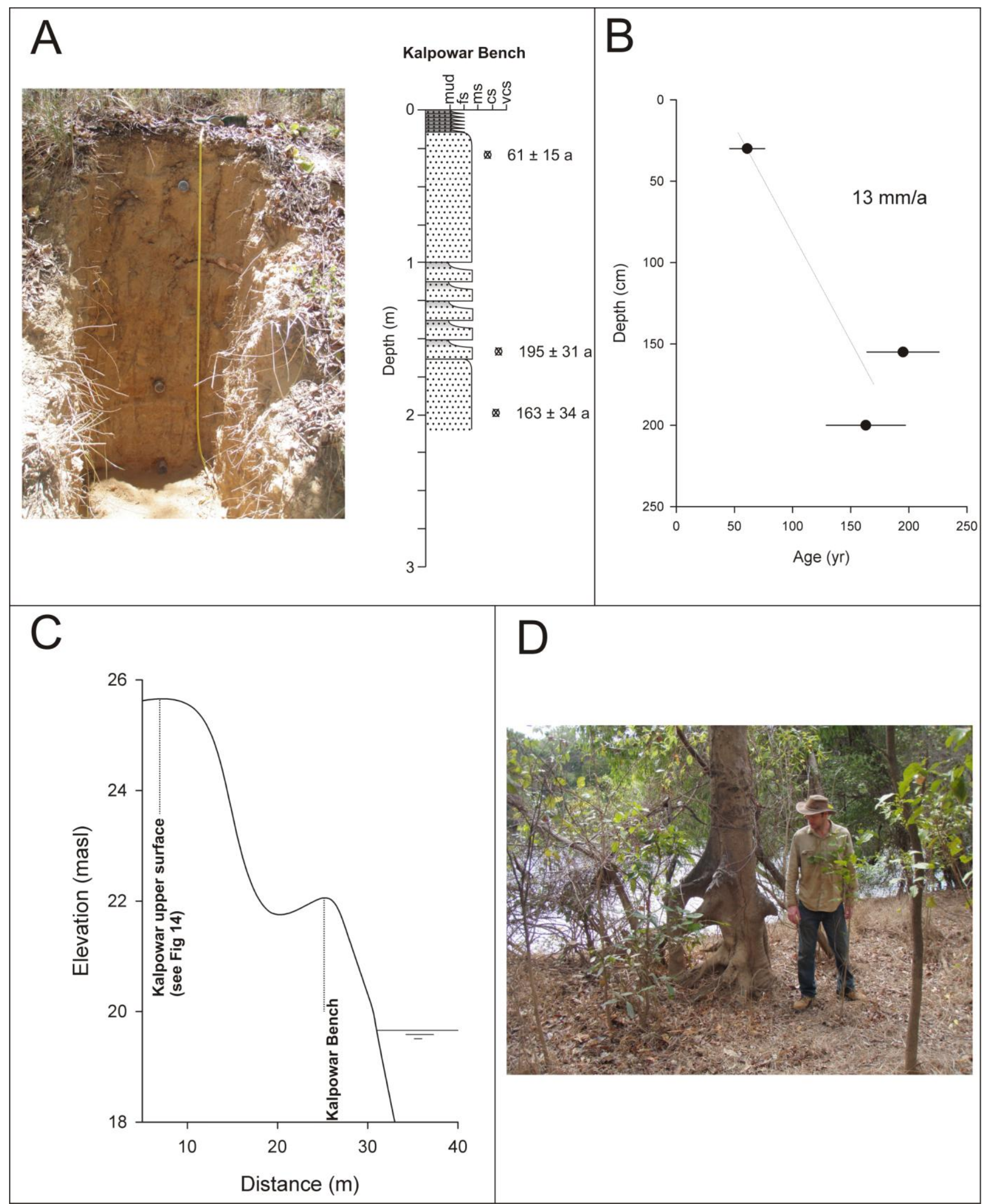

Figure 10 
Page 32 of 43

ACCEPTED MANUSCRIPT

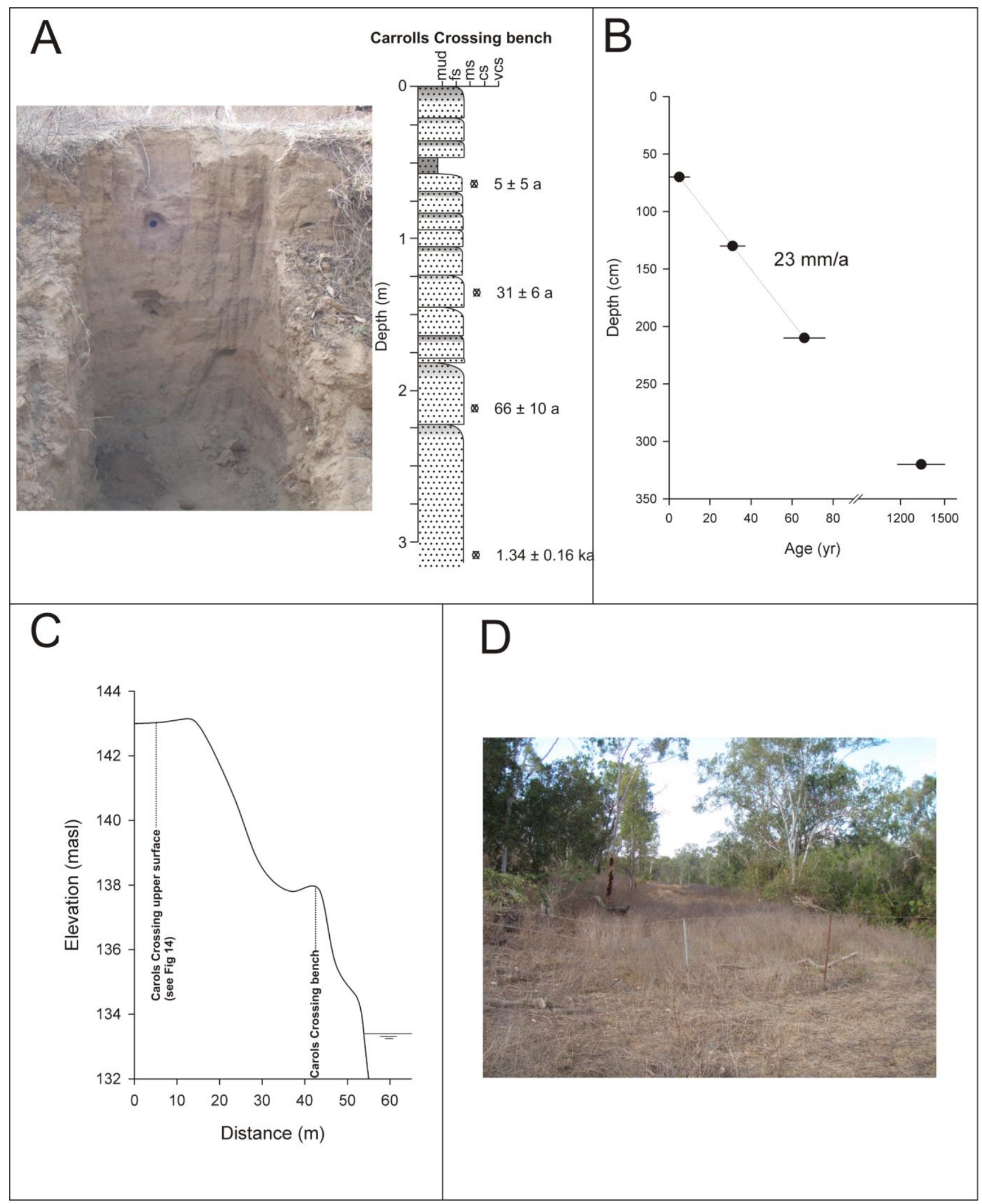

Figure 11 
Page $\mathbf{3 3}$ of $\mathbf{4 3}$
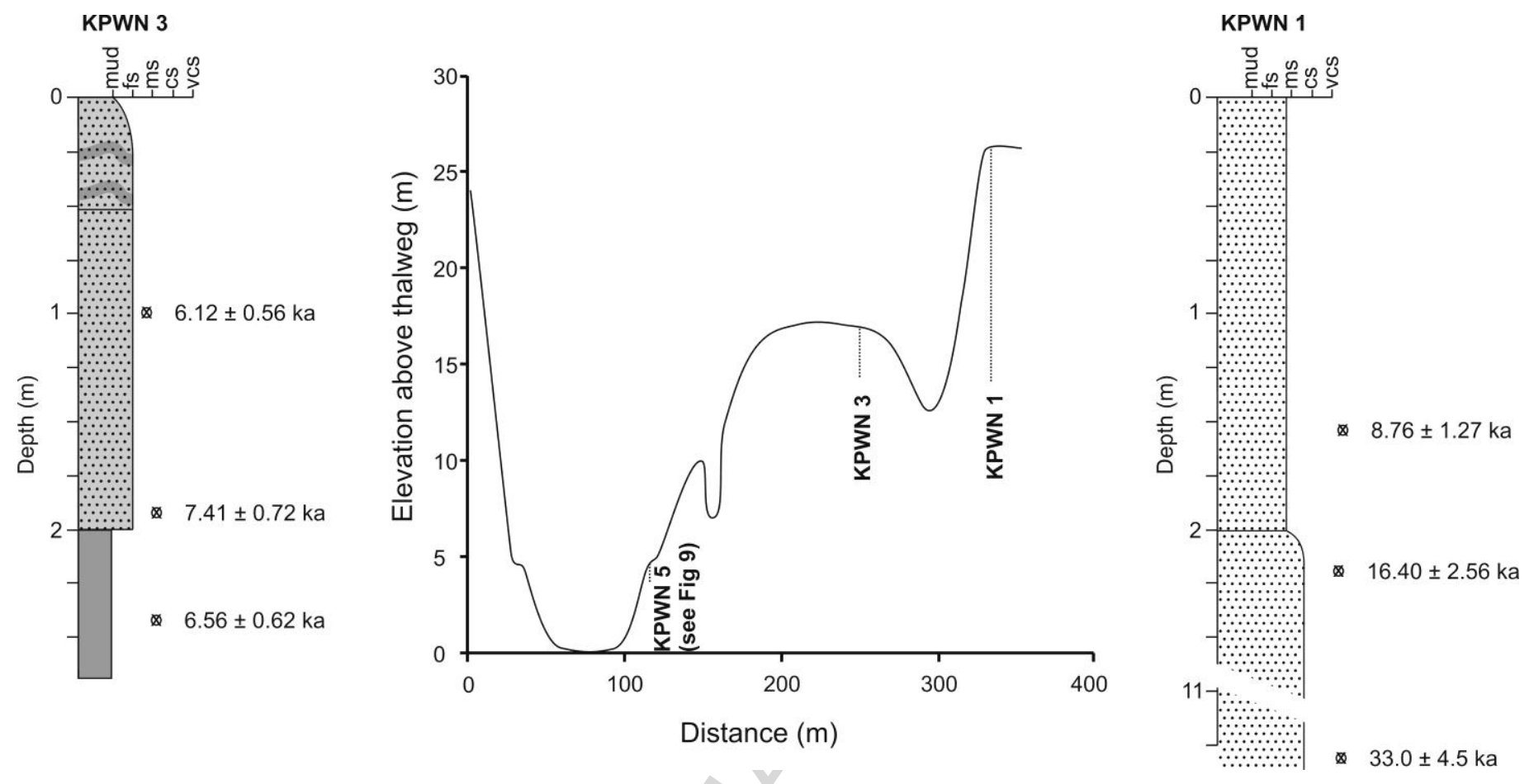

Figure 12 
Page 34 of $\mathbf{4 3}$

\section{ACCEPTED MANUSCRIPT}

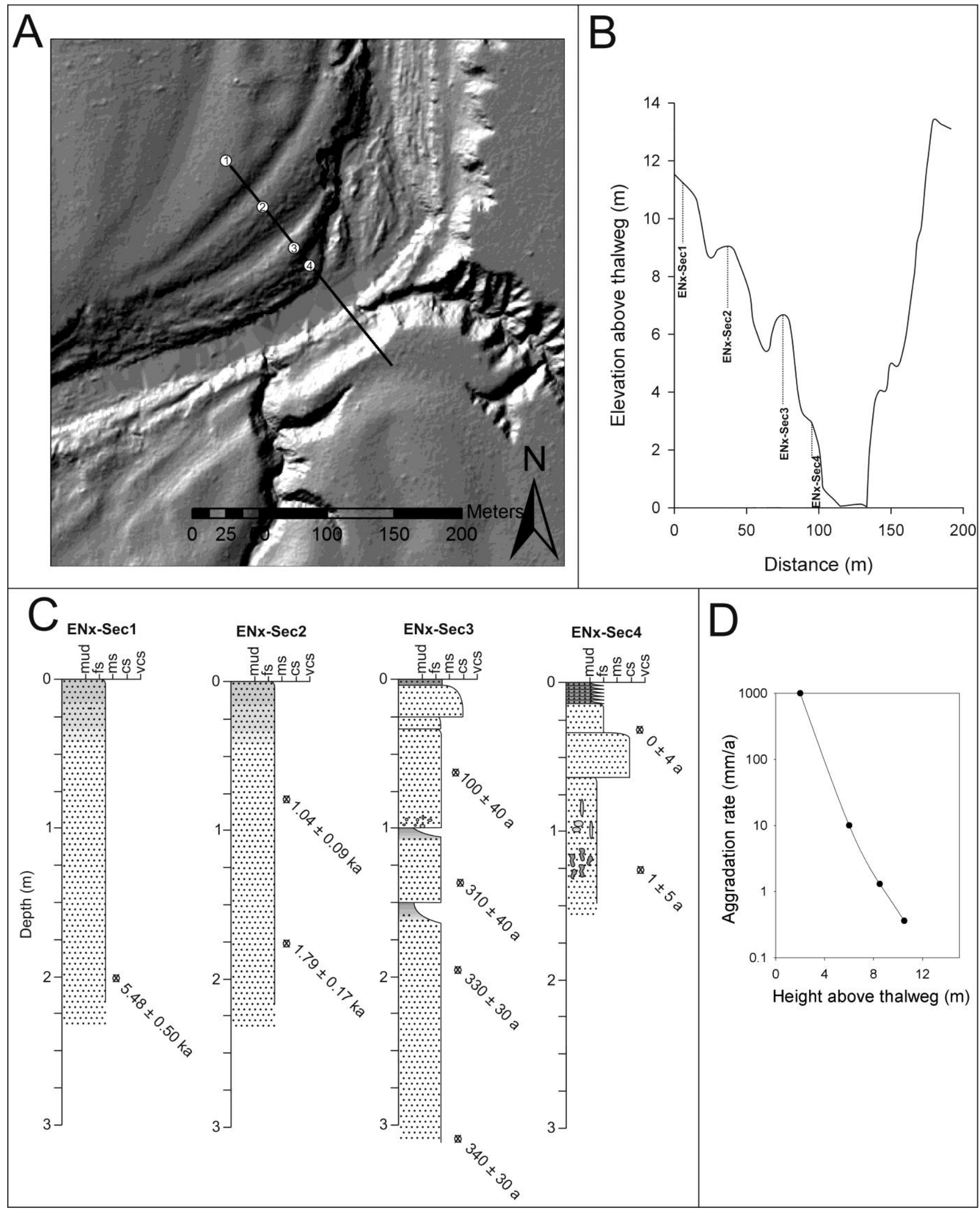

Figure 13 
Page $\mathbf{3 5}$ of $\mathbf{4 3}$

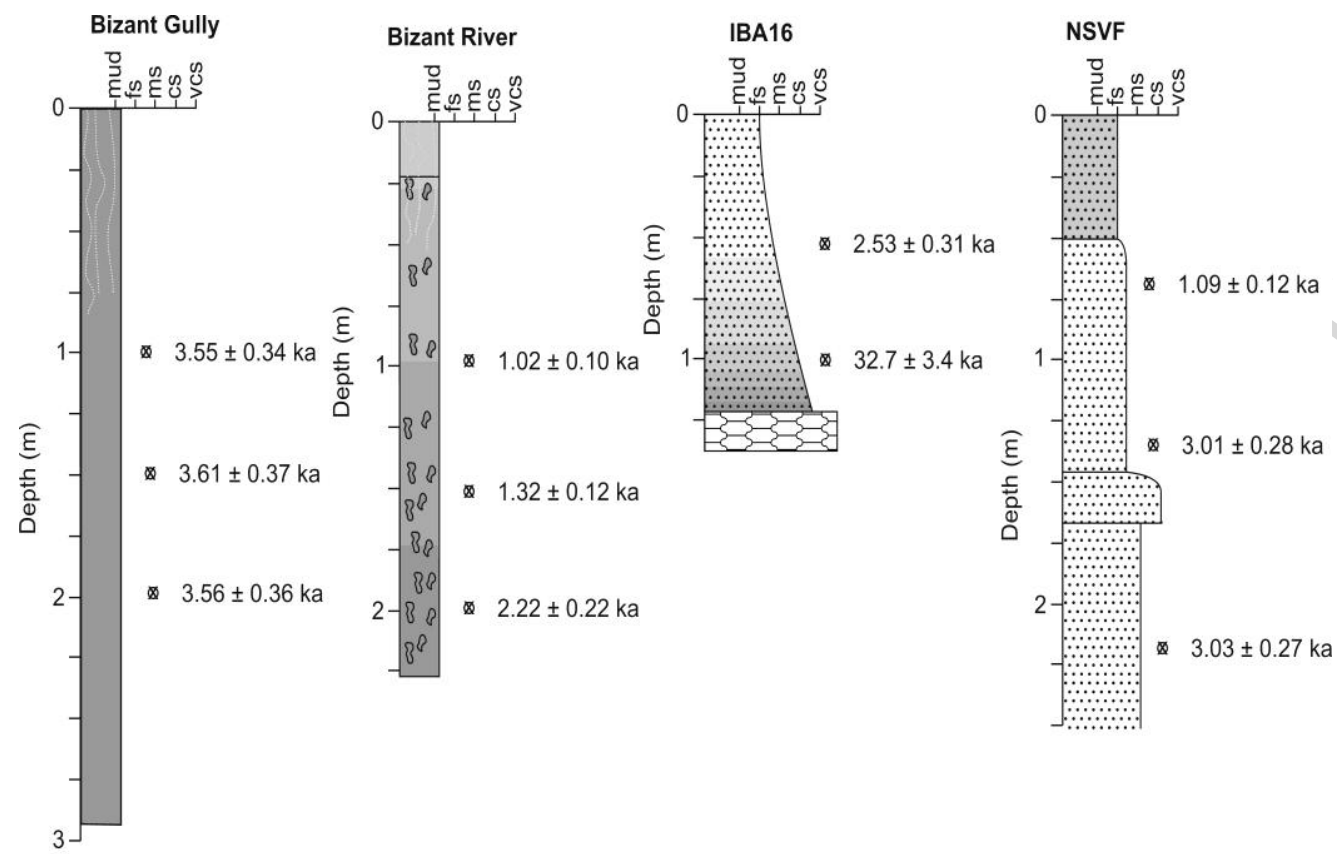

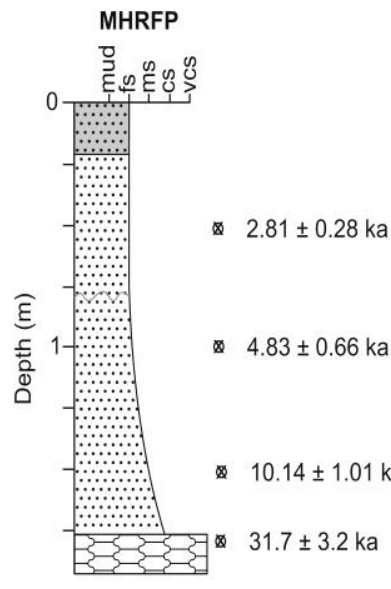

Carrolls Crossing upper surface

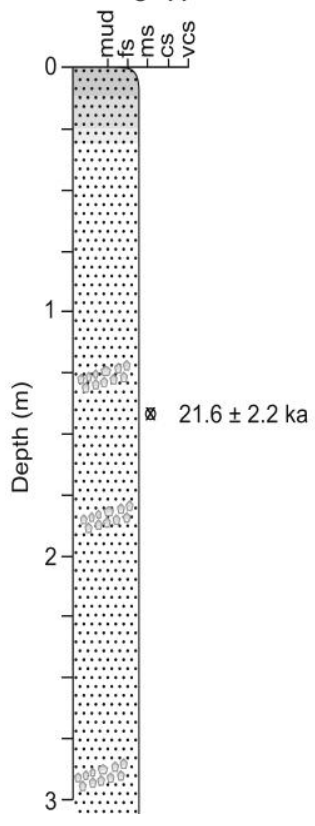

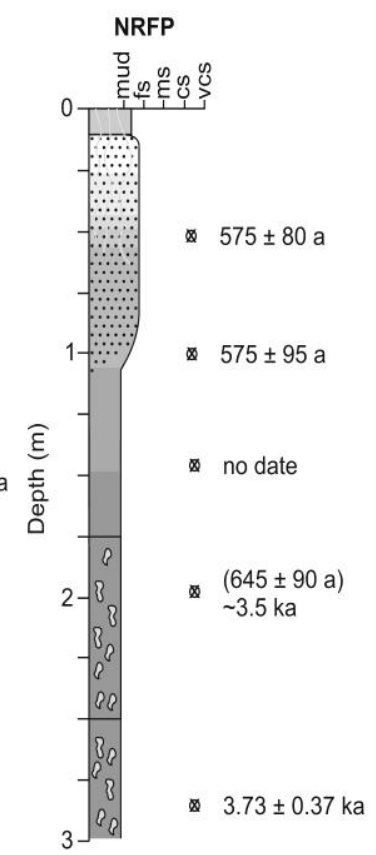

Kalpower upper surface

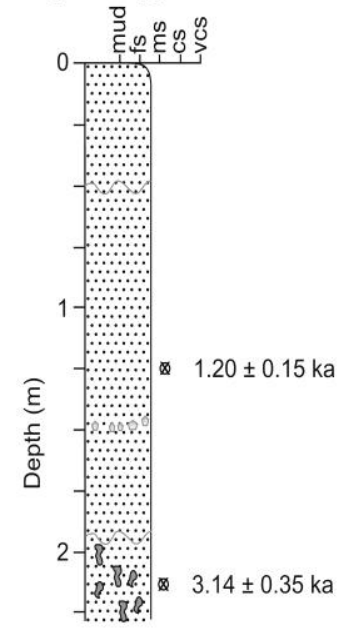
Legend
gravel
$\therefore$ a.:. sand
$\square$ mud
silt
Ez saprolite
B P mottles
- OSL date 
Page 36 of 43

ACCEPTED MANUSCRIPT
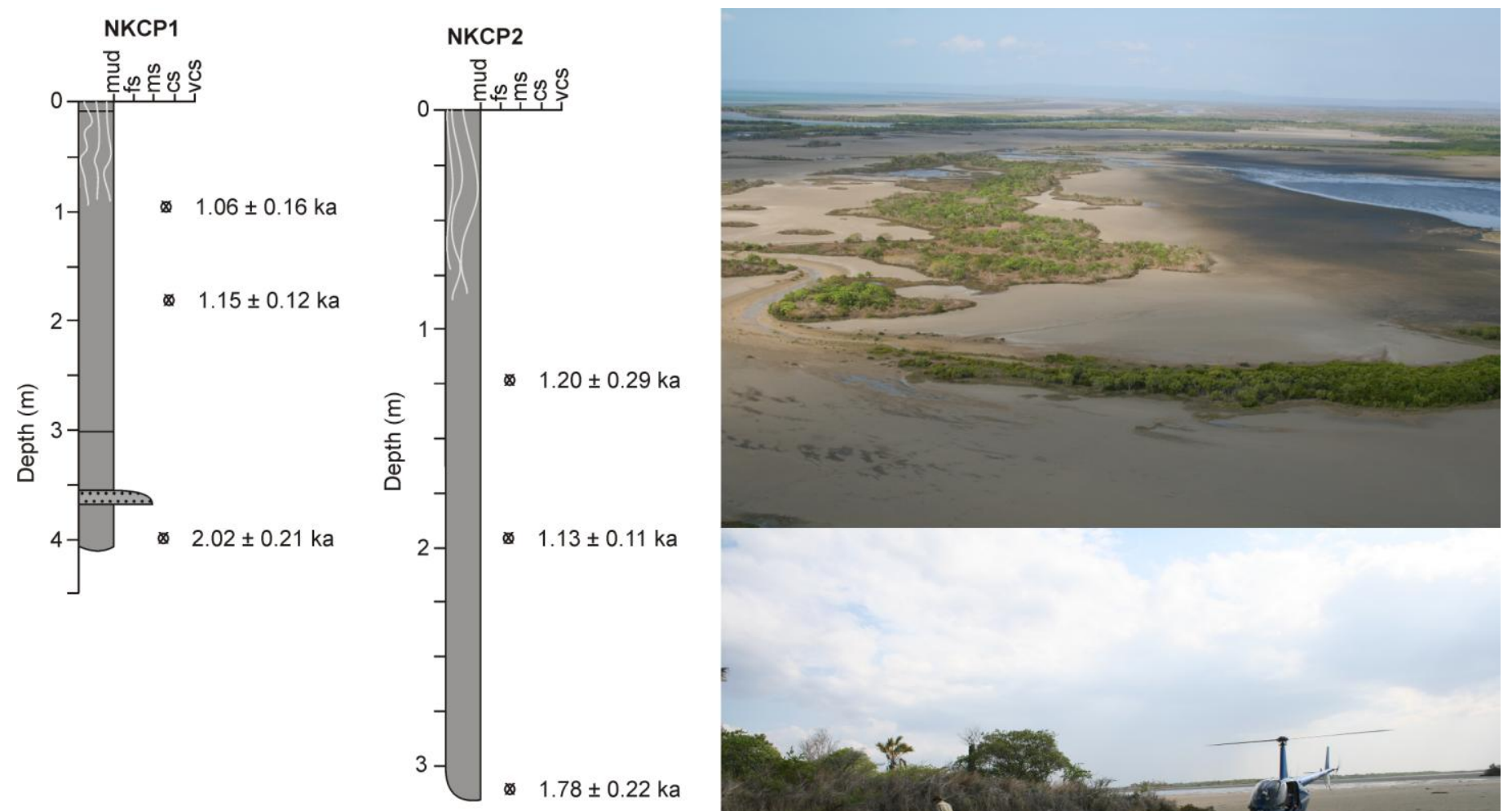

Figure 15

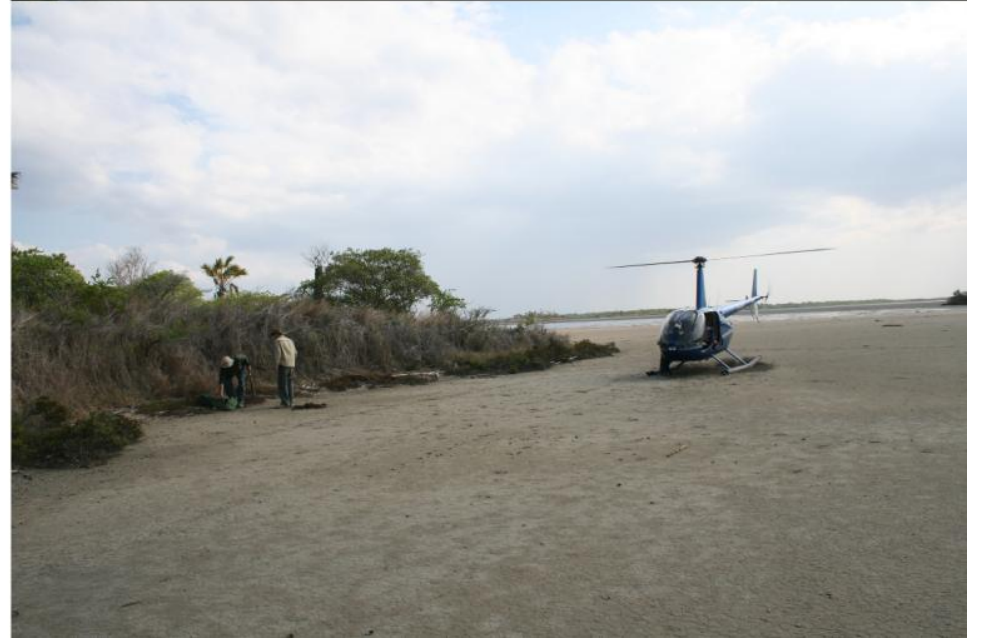


Page $\mathbf{3 7}$ of $\mathbf{4 3}$

ACCEPTED MANUSCRIPT
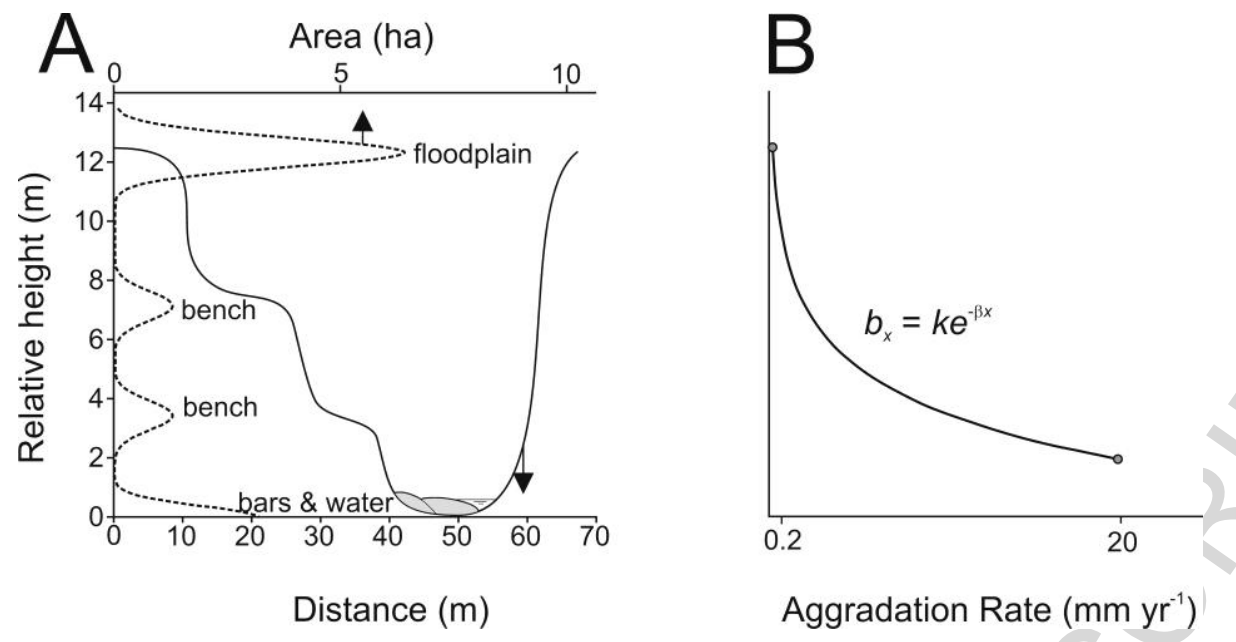

Figure 16 

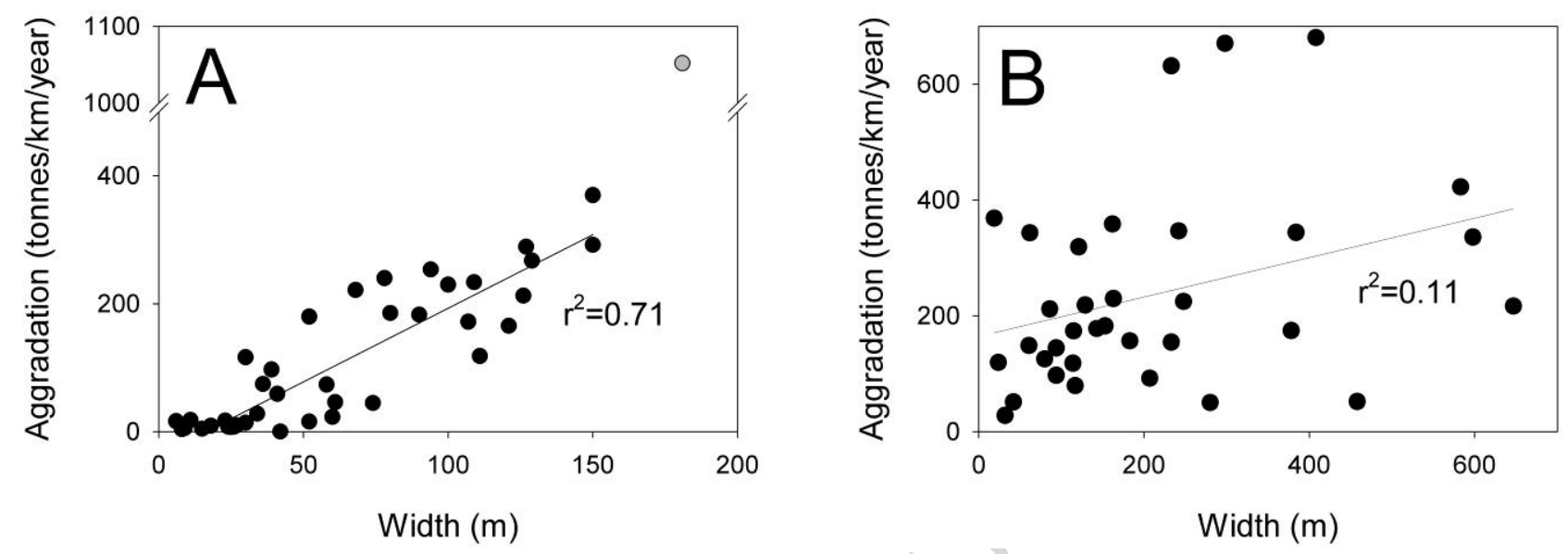

Figure 17 


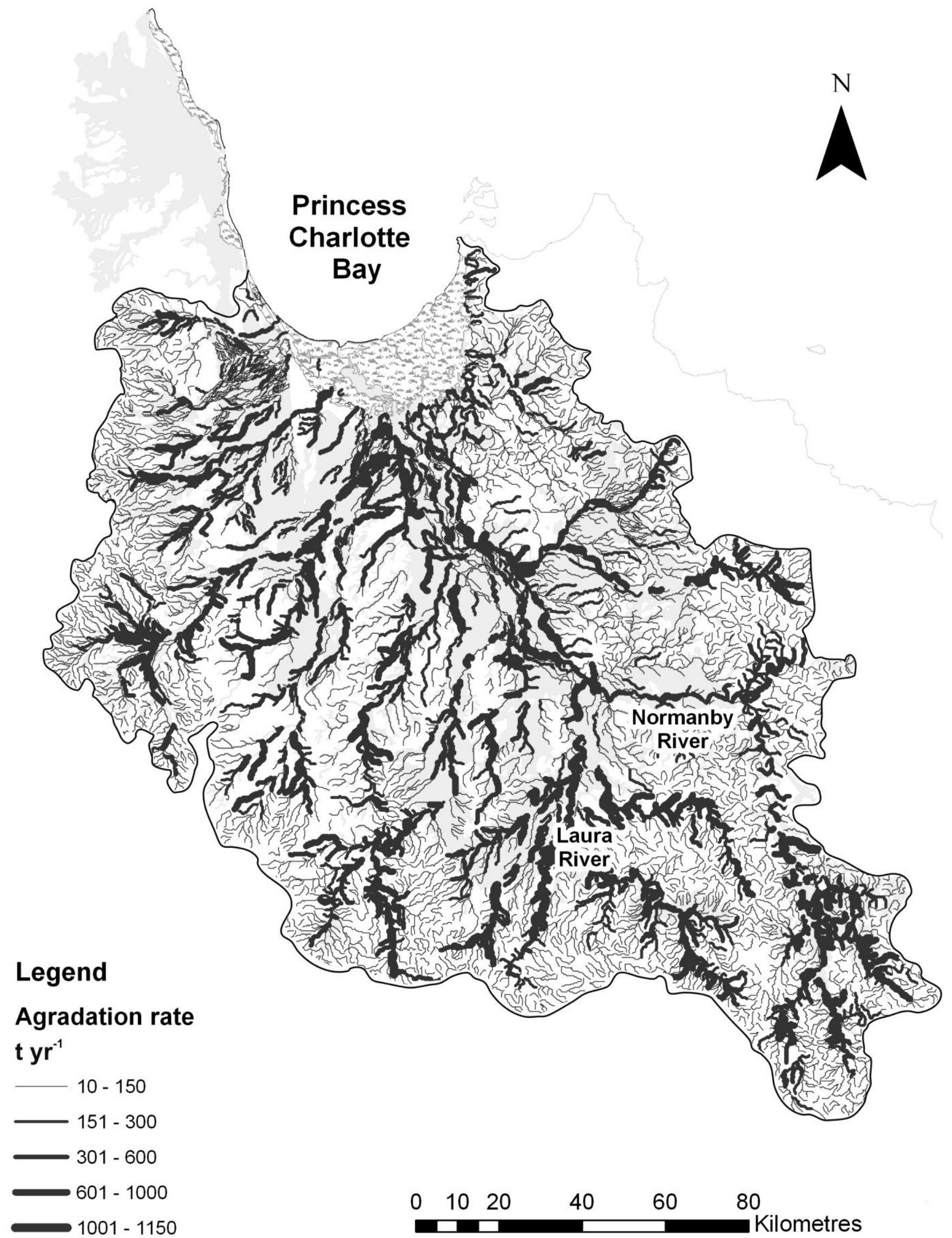


Table 1. Details of study reaches and estimated aggradation volumes.

\begin{tabular}{|c|c|c|c|c|c|c|c|}
\hline $\begin{array}{c}\text { LiDAR } \\
\text { Block }\end{array}$ & Stream & Location & $\begin{array}{c}\text { Catchment } \\
\text { Area } \\
\left(\mathbf{k m}^{2}\right)\end{array}$ & $\begin{array}{c}\text { Depositional } \\
\text { Area } \\
\text { (ha) }\end{array}$ & $\begin{array}{c}\text { Thalweg } \\
\text { Length } \\
\text { (m) }\end{array}$ & $\begin{array}{c}\text { Annual } \\
\text { depositional } \\
\text { volume } \\
\left(\mathbf{m}^{\mathbf{3}}\right)\end{array}$ & $\begin{array}{c}\text { Annual } \\
\text { fines } \\
\text { aggradation } \\
\text { (tonnes } / \mathbf{k m} \text { ) }\end{array}$ \\
\hline \multicolumn{8}{|c|}{ Major Channels } \\
\hline 1 & Laura R & $15.88^{\circ} \mathrm{S}, 144.78^{\circ} \mathrm{E}$ & 128 & 34.5 & 5038 & 522 & 48.5 \\
\hline 17 & Laura $\mathrm{R}$ & $15.72^{\circ} \mathrm{S}, 144.68^{\circ} \mathrm{E}$ & 564 & 38.7 & 2799 & 678 & 113.3 \\
\hline 16 & Laura $\mathrm{R}$ & $15.68^{\circ} \mathrm{S}, 144.60^{\circ} \mathrm{E}$ & 753 & 23.9 & 5024 & 1203 & 112.1 \\
\hline 6 & West Normanby R & $15.92^{\circ} \mathrm{S}, 144.92^{\circ} \mathrm{E}$ & 304 & 18.6 & 6410 & 798 & 58.3 \\
\hline 4 & Normanby R & $15.76^{\circ} \mathrm{S}, 144.97^{\circ} \mathrm{E}$ & 840 & 48.8 & 5781 & 4116 & 333.2 \\
\hline 5 & Normanby R & $15.66^{\circ} \mathrm{S}, 144.94^{\circ} \mathrm{E}$ & 1049 & 129.1 & 5887 & 5861 & 465.9 \\
\hline 10 & Normanby $R$ & $15.60^{\circ} \mathrm{S}, 144.91^{\circ} \mathrm{E}$ & 1745 & 184.3 & 5118 & 5729 & 523.9 \\
\hline 12 & Normanby $\mathrm{R}$ & $15.50^{\circ} \mathrm{S}, 144.87^{\circ} \mathrm{E}$ & 1957 & 134.8 & 6725 & 4387 & 305.3 \\
\hline 13 & Normanby R & $15.35^{\circ} \mathrm{S}, 144.85^{\circ} \mathrm{E}$ & 2158 & 98.4 & 5799 & 1422 & 114.8 \\
\hline 14 & Normanby R & $15.25^{\circ} \mathrm{S}, 144.59^{\circ} \mathrm{E}$ & 3016 & 280.5 & 5793 & 3862 & 312 \\
\hline 29 & Normanby R & $15.09^{\circ} \mathrm{S}, 144.34^{\circ} \mathrm{E}$ & 8100 & 40 & 1853 & 665 & 168 \\
\hline 32 & Normanby R & $14.79^{\circ} \mathrm{S}, 144.20^{\circ} \mathrm{E}$ & 12937 & 6.2 & 1367 & 260 & 88.9 \\
\hline 8 & East Normanby R & $15.89^{\circ} \mathrm{S}, 145.15^{\circ} \mathrm{E}$ & 45 & 26.9 & 2816 & 1906 & 316.7 \\
\hline 9 & East Normanby R & $15.81^{\circ} \mathrm{S}, 145.07^{\circ} \mathrm{E}$ & 193 & 60.7 & 3952 & 1318 & 156.1 \\
\hline 4 & East Normanby R & $15.75^{\circ} \mathrm{S}, 145.01^{\circ} \mathrm{E}$ & 301 & 62.8 & 5906 & 1106 & 87.6 \\
\hline 11 & East Normanby R & $15.68^{\circ} \mathrm{S}, 144.98^{\circ} \mathrm{E}$ & 339 & 23.8 & 6200 & 925 & 69.8 \\
\hline 21 & Kennedy R & $15.58^{\circ} \mathrm{S}, 144.01^{\circ} \mathrm{E}$ & 1067 & 63.8 & 7308 & 2044 & 130.9 \\
\hline 23 & Kennedy R & $15.53^{\circ} \mathrm{S}, 144.08^{\circ} \mathrm{E}$ & 1146 & 15.6 & 1891 & 523 & 129.3 \\
\hline 22 & Kennedy R & $15.20^{\circ} \mathrm{S}, 144.21^{\circ} \mathrm{E}$ & 1770 & 16.3 & 4363 & 337 & 36.2 \\
\hline 28 & North Kennedy R & $14.97^{\circ} \mathrm{S}, 144.18^{\circ} \mathrm{E}$ & 839 & 12.9 & 2101 & 344 & 76.6 \\
\hline 38 & Hann R & $15.19^{\circ} \mathrm{S}, 144.87^{\circ} \mathrm{E}$ & 1004 & 3 & 2818 & 70 & 11.7 \\
\hline 27 & North Kennedy R & $14.93^{\circ} \mathrm{S}, 144.10^{\circ} \mathrm{E}$ & 12073 & 62.6 & 5095 & 1801 & 165.4 \\
\hline 35 & North Kennedy R & $14.89^{\circ} \mathrm{S}, 144.09^{\circ} \mathrm{E}$ & 12220 & 65.7 & 4122 & 1692 & 192.1 \\
\hline 26 & North Kennedy R & $14.91^{\circ} \mathrm{S}, 144.14^{\circ} \mathrm{E}$ & 14055 & 114.9 & 7367 & 2016 & 128.1 \\
\hline 25 & North Kennedy R & $14.73^{\circ} \mathrm{S}, 144.07^{\circ} \mathrm{E}$ & 18526 & 19.2 & 1180 & 520 & 206.2 \\
\hline 37 & Healy $\mathrm{Ck}$ & $14.97^{\circ} \mathrm{S}, 144.86^{\circ} \mathrm{E}$ & 544 & 6 & 4155 & 331 & 37.3 \\
\hline 40 & Morehead R & $14.95^{\circ} \mathrm{S}, 143.80^{\circ} \mathrm{E}$ & 1642 & 153.9 & 8216 & 6195 & 352.9 \\
\hline 36 & Morehead R & $14.94^{\circ} \mathrm{S}, 143.89^{\circ} \mathrm{E}$ & 1673 & 22 & 5642 & 1078 & 89.4 \\
\hline 2 & Bizant R & $14.66^{\circ} \mathrm{S}, 144.12^{\circ} \mathrm{E}$ & 16457 & 63 & 10262 & 4619 & 210.7 \\
\hline 34 & Saltwater $\mathrm{Ck}$ & $14.61^{\circ} \mathrm{S}, 143.90^{\circ} \mathrm{E}$ & 1151 & 47.1 & 2381 & 1745 & 342.9 \\
\hline
\end{tabular}

\section{Minor Channels}

\begin{tabular}{|c|c|c|}
\hline 2 & & $14.68^{\circ} \mathrm{S}, 144.14^{\circ} \mathrm{E}$ \\
\hline 2 & Ferguson $\mathrm{Ck}$ & $14.65^{\circ} \mathrm{S}, 144.15^{\circ} \mathrm{E}$ \\
\hline 3 & Boggy Ck & $15.79^{\circ} \mathrm{S}, 144.92^{\circ} \mathrm{E}$ \\
\hline 7 & Sporing Ck & $15.93^{\circ} \mathrm{S}, 145.03^{\circ} \mathrm{E}$ \\
\hline 7 & Parsons Ck & $15.94^{\circ} \mathrm{S}, 145.00^{\circ} \mathrm{E}$ \\
\hline 7 & Sporing Ck & $15.93^{\circ} \mathrm{S}, 145.01^{\circ} \mathrm{E}$ \\
\hline 7 & Granite Normanby R & $15.94^{\circ} \mathrm{S}, 145.01^{\circ} \mathrm{E}$ \\
\hline 7 & Granite Normanby R & $15.91^{\circ} \mathrm{S}, 144.99^{\circ} \mathrm{E}$ \\
\hline 9 & Welch Ck & $15.80^{\circ} \mathrm{S}, 145.08^{\circ} \mathrm{E}$ \\
\hline 11 & & $15.69^{\circ} \mathrm{S}, 145.00^{\circ} \mathrm{E}$ \\
\hline 11 & Christmas Lagoons & $15.67^{\circ} \mathrm{S}, 144.99^{\circ} \mathrm{E}$ \\
\hline 11 & & $15.70^{\circ} \mathrm{S}, 145.09^{\circ} \mathrm{E}$ \\
\hline 12 & & $15.51^{\circ} \mathrm{S}, 144.87^{\circ} \mathrm{E}$ \\
\hline 12 & & $15.50^{\circ} \mathrm{S}, 144.85^{\circ} \mathrm{E}$ \\
\hline 13 & Clayhole Ck & $15.36^{\circ} \mathrm{S}, 144.82^{\circ} \mathrm{E}$ \\
\hline 13 & Puckley Ck & $15.37^{\circ} \mathrm{S}, 144.82^{\circ} \mathrm{E}$ \\
\hline 13 & & $15.38^{\circ} \mathrm{S}, 144.85^{\circ} \mathrm{E}$ \\
\hline 14 & & $15.21^{\circ} \mathrm{S}, 144.55^{\circ} \mathrm{E}$ \\
\hline 16 & Earls Ck & $15.68^{\circ} \mathrm{S}, 144.60^{\circ} \mathrm{E}$ \\
\hline 17 & & $15.70^{\circ} \mathrm{S}, 144.68^{\circ} \mathrm{E}$ \\
\hline 18 & Earls Ck & $15.71^{\circ} \mathrm{S}, 144.60^{\circ} \mathrm{E}$ \\
\hline 19 & Mosman R & $15.68^{\circ} \mathrm{S}, 144.38^{\circ} \mathrm{E}$ \\
\hline 20 & Mosman R & $15.58^{\circ} \mathrm{S}, 144.40^{\circ} \mathrm{E}$ \\
\hline 22 & & $15.19^{\circ} \mathrm{S}, 144.22^{\circ} \mathrm{E}$ \\
\hline 23 & & $15.52^{\circ} \mathrm{S}, 144.08^{\circ} \mathrm{E}$ \\
\hline 23 & & $15.51^{\circ} \mathrm{S}, 144.05^{\circ} \mathrm{E}$ \\
\hline 24 & & $15.05^{\circ} \mathrm{S}, 144.10^{\circ} \mathrm{E}$ \\
\hline 24 & & $15.08^{\circ} \mathrm{S}, 144.07^{\circ} \mathrm{E}$ \\
\hline 24 & & $15.06^{\circ} \mathrm{S}, 144.09^{\circ} \mathrm{E}$ \\
\hline 27 & & $14.96^{\circ} \mathrm{S}, 144.10^{\circ} \mathrm{E}$ \\
\hline 28 & Catfish Ck & $15.00^{\circ} \mathrm{S}, 144.22^{\circ} \mathrm{E}$ \\
\hline 28 & Catfish Ck & $14.97^{\circ} \mathrm{S}, 144.19^{\circ} \mathrm{E}$ \\
\hline 30 & & $15.13^{\circ} \mathrm{S}, 144.40^{\circ} \mathrm{E}$ \\
\hline 36 & & $14.92^{\circ} \mathrm{S}, 143.87^{\circ} \mathrm{E}$ \\
\hline 37 & & $15.00^{\circ} \mathrm{S}, 143.88^{\circ} \mathrm{E}$ \\
\hline 39 & & $15.17^{\circ} \mathrm{S}, 143.48^{\circ} \mathrm{E}$ \\
\hline 39 & & $15.21^{\circ} \mathrm{S}, 143.44^{\circ} \mathrm{E}$ \\
\hline 39 & & $15.21^{\circ} \mathrm{S}, 143.45^{\circ} \mathrm{E}$ \\
\hline 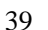 & & $15.19^{\circ} \mathrm{S}, 143.49^{\circ} \mathrm{F}$ \\
\hline
\end{tabular}

\begin{tabular}{|c|c|c|}
\hline 13080 & 4.6 & 2771 \\
\hline 13092 & 5.9 & 3582 \\
\hline 76 & 161.9 & 9106 \\
\hline 58 & 44.5 & 4102 \\
\hline 11 & 5.6 & 2076 \\
\hline 65 & 14.6 & 2122 \\
\hline 247 & 46.3 & 5781 \\
\hline 321 & 43 & 4623 \\
\hline 16 & 33.3 & 3506 \\
\hline 15 & 7.8 & 5000 \\
\hline 179 & 11.4 & 5548 \\
\hline 10 & 5.2 & 2951 \\
\hline 7 & 8.9 & 2335 \\
\hline 23 & 46.9 & 6929 \\
\hline 9 & 87.0 & 9674 \\
\hline 49 & 108.0 & 9667 \\
\hline 11 & 66.8 & 5886 \\
\hline 20 & 65.1 & 3952 \\
\hline 23 & 21.2 & 1925 \\
\hline 9 & 62.2 & 3770 \\
\hline 7 & 14.7 & 5146 \\
\hline 354 & 113.6 & 3094 \\
\hline 392 & 64.8 & 4341 \\
\hline 48 & 31.4 & 2180 \\
\hline 16 & 3.9 & 1403 \\
\hline 3 & 0.1 & 747 \\
\hline 153 & 97.4 & 6755 \\
\hline 47 & 5.5 & 3372 \\
\hline 100 & 4.9 & 6056 \\
\hline 315 & 21.4 & 8283 \\
\hline 10666 & 0.3 & 876 \\
\hline 10876 & 11.4 & 3205 \\
\hline 69 & 145.8 & 11809 \\
\hline 1676 & 26.5 & 3294 \\
\hline 1090 & 4.1 & 9190 \\
\hline 25 & 0.3 & 1257 \\
\hline 6 & 5.7 & 2381 \\
\hline 11 & 14.7 & 3955 \\
\hline
\end{tabular}

$\begin{array}{cc}40 & 6.8 \\ 119 & 15.5 \\ 5974 & 307.1 \\ 2100 & 239.6 \\ 328 & 74.0 \\ 806 & 177.8 \\ 2365 & 191.5 \\ 2462 & 249.2 \\ 2186 & 291.7 \\ 144 & 13.5 \\ 271 & 22.8 \\ 114 & 18.1 \\ 824 & 165.2 \\ 3456 & 233.5 \\ 6742 & 326.2 \\ 4568 & 221.2 \\ 3634 & 288.9 \\ 1541 & 182.5 \\ 398 & 96.8 \\ 2968 & 368.4 \\ 644 & 58.6 \\ 3725 & 563.4 \\ 1767 & 190.5 \\ 1179 & 253.1 \\ 137 & 45.7 \\ 12 & 7.3 \\ 3502 & 242.7 \\ 113 & 15.6 \\ 122 & 9.4 \\ 853 & 48.2 \\ 8 & 4.3 \\ 499 & 72.9 \\ 4521 & 179.2 \\ 829 & 117.8 \\ 148 & 7.5 \\ 9 & 3.3 \\ 85 & 16.6 \\ 236 & 27.9 \\ 11 & 5.3\end{array}$


Table 2. OSL data for each sample.

\begin{tabular}{|c|c|c|c|c|c|c|c|c|}
\hline Sample & ${ }^{238} \mathbf{U}$ & ${ }^{226} \mathbf{R a}$ & ${ }^{210} \mathrm{~Pb}$ & ${ }^{232} \mathrm{Th}$ & ${ }^{40} \mathbf{K}$ & $\begin{array}{c}\text { D.R. } \\
\text { (Gy/ka) }\end{array}$ & $D_{\mathrm{e}}(\mathrm{Gy})$ & Age \\
\hline GU 2.1 Battlecamp Crossing $110 \mathrm{~cm}$ & $25.1 \pm 1.8$ & $25.5 \pm 0.4$ & $27.2 \pm 2.2$ & $33 \pm 0$ & $476 \pm 11$ & $2.44 \pm 0.18$ & $0.23 \pm 0.014$ & $95 \pm 10 \mathrm{a}$ \\
\hline GU 2.2 Battlecamp Crossing $320 \mathrm{~cm}$ & $44 \pm 2$ & $43 \pm 1$ & $39 \pm 3$ & $55 \pm 1$ & $483 \pm 11$ & $2.98 \pm 0.25$ & $0.48 \pm 0.02$ & $160 \pm 15 \mathrm{a}$ \\
\hline GU 2.3 Bizant Gully $100 \mathrm{~cm}$ & $52 \pm 3$ & $57 \pm 1$ & $53 \pm 3$ & $74 \pm 1$ & $483 \pm 11$ & $3.55 \pm 0.31$ & $12.61 \pm 0.32$ & $3.55 \pm 0.34 \mathrm{ka}$ \\
\hline GU 2.4 Bizant Gully $150 \mathrm{~cm}$ & $60 \pm 3$ & $56 \pm 1$ & $52 \pm 3$ & $79 \pm 1$ & $475 \pm 11$ & $3.60 \pm 0.32$ & $12.99 \pm 0.52$ & $3.61 \pm 0.37 \mathrm{ka}$ \\
\hline GU 2.5 Bizant Gully $200 \mathrm{~cm}$ & $61 \pm 3$ & $67 \pm 1$ & $66 \pm 3$ & $80 \pm 1$ & $432 \pm 10$ & $3.68 \pm 0.33$ & $13.09 \pm 0.40$ & $3.56 \pm 0.36 \mathrm{ka}$ \\
\hline GU 2.6 Bizant River $100 \mathrm{~cm}$ & $45 \pm 2$ & $42 \pm 1$ & $36 \pm 3$ & $58 \pm 1$ & $350 \pm 9$ & $2.69 \pm 0.24$ & $2.74 \pm 0.078$ & $1.02 \pm 0.10 \mathrm{ka}$ \\
\hline GU 2.7 Bizant River $150 \mathrm{~cm}$ & $43 \pm 2$ & $34 \pm 0$ & $36 \pm 2$ & $58 \pm 1$ & $323 \pm 7$ & $2.58 \pm 0.23$ & $3.42 \pm 0.052$ & $1.32 \pm 0.12 \mathrm{ka}$ \\
\hline GU 2.8 Bizant River $200 \mathrm{~cm}$ & $45 \pm 2$ & $54 \pm 1$ & $53 \pm 2$ & $58 \pm 1$ & $266 \pm 6$ & $2.65 \pm 0.24$ & $5.88 \pm 0.078$ & $2.22 \pm 0.22 \mathrm{ka}$ \\
\hline GU 2.9 IBA 16 Floodplain $100 \mathrm{~cm}$ & $19.7 \pm 1.0$ & $17.4 \pm 0.3$ & $16.8 \pm 1.2$ & $21.8 \pm 0.4$ & $28.9 \pm 1.3$ & $0.89 \pm 0.09$ & $29.0 \pm 0.8$ & $32.7 \pm 3.4 \mathrm{ka}$ \\
\hline GU 2.10 IBA 16 Floodplain $50 \mathrm{~cm}$ & $43 \pm 1$ & $40 \pm 1$ & $35 \pm 2$ & $51 \pm 1$ & $60 \pm 2$ & $1.78 \pm 0.18$ & $4.5 \pm 0.3$ & $2.53 \pm 0.31 \mathrm{ka}$ \\
\hline GU 2.11 Kingsplains Pit $1150 \mathrm{~cm}$ & $48 \pm 2$ & $44 \pm 1$ & $46 \pm 2$ & $66 \pm 1$ & $693 \pm 14$ & $3.88 \pm 0.31$ & $34 \pm 4$ & $8.76 \pm 1.27 \mathrm{ka}$ \\
\hline GU 2.12 Kingsplains Pit $1220 \mathrm{~cm}$ & $19.7 \pm 1.0$ & $17.8 \pm 0.3$ & $30 \pm 2$ & $27.0 \pm 0.4$ & $757 \pm 16$ & $3.11 \pm 0.21$ & $51 \pm 7$ & $16.40 \pm 2.56 \mathrm{ka}$ \\
\hline GU 2.13 Kingsplains Pit 1 base & $49 \pm 2$ & $42 \pm 1$ & $39 \pm 3$ & $55 \pm 1$ & $523 \pm 12$ & $3.03 \pm 0.26$ & $100 \pm 10$ & $33.0 \pm 4.5 \mathrm{ka}$ \\
\hline GU 2.15 Kingsplains Pit $3100 \mathrm{~cm}$ & $46 \pm 2$ & $43 \pm 1$ & $39 \pm 3$ & $61 \pm 1$ & $545 \pm 12$ & $3.30 \pm 0.27$ & $20.15 \pm 0.54$ & $6.12 \pm 0.56 \mathrm{ka}$ \\
\hline GU 2.16 Kingsplains Pit $3190 \mathrm{~cm}$ & $49 \pm 2$ & $42 \pm 1$ & $37 \pm 2$ & $63 \pm 1$ & $485 \pm 10$ & $3.13 \pm 0.26$ & $23.2 \pm 0.9$ & $7.41 \pm 0.72 \mathrm{ka}$ \\
\hline GU 2.17 Kingsplains Pit $3240 \mathrm{~cm}$ & $50 \pm 2$ & $49 \pm 1$ & $43 \pm 2$ & $66 \pm 1$ & $546 \pm 12$ & $3.43 \pm 0.29$ & $22.5 \pm 0.75$ & $6.56 \pm 0.62 \mathrm{ka}$ \\
\hline GU 2.19 Kingsplains Pit $5100 \mathrm{~cm}$ & $38 \pm 2$ & $38 \pm 1$ & $36 \pm 2$ & $52 \pm 1$ & $495 \pm 11$ & $2.96 \pm 0.24$ & $1.28 \pm 0.05$ & $430 \pm 41 \mathrm{a}$ \\
\hline GU 2.20 Kingsplains Pit $5150 \mathrm{~cm}$ & $39 \pm 2$ & $38 \pm 1$ & $39 \pm 3$ & $54 \pm 1$ & $487 \pm 11$ & $2.99 \pm 0.25$ & $1.96 \pm 0.07$ & $660 \pm 62 \mathrm{a}$ \\
\hline GU 2.21 Morehead R. FP $150 \mathrm{~cm}$ & $44 \pm 2$ & 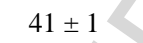 & $37 \pm 2$ & $44 \pm 1$ & $205 \pm 5$ & $2.09 \pm 0.19$ & $5.88 \pm 0.16$ & $2.81 \pm 0.28 \mathrm{ka}$ \\
\hline GU 2.22 Morehead R. FP $1100 \mathrm{~cm}$ & $21.9 \pm 0.9$ & $21.5 \pm 0.3$ & $20.8 \pm 1.1$ & $22.7 \pm 0.3$ & $58 \pm 2$ & $1.04 \pm 0.10$ & $5.02 \pm 0.49$ & $4.83 \pm 0.66 \mathrm{ka}$ \\
\hline GU 2.23 Morehead R. FP $1150 \mathrm{~cm}$ & $18.0 \pm 0.8$ & $18.1 \pm 0.2$ & $18.4 \pm 1.1$ & $20.0 \pm 0.3$ & $37 \pm 1$ & $0.89 \pm 0.08$ & $9.02 \pm 0.06$ & $10.14 \pm 1.01 \mathrm{ka}$ \\
\hline GU 2.24 Morehead R. FP $1180 \mathrm{~cm}$ & $12.1 \pm 0.7$ & $10.5 \pm 0.2$ & $11.2 \pm 0.8$ & $11.8 \pm 0.2$ & $22.2 \pm 1.0$ & $0.60 \pm 0.06$ & $18.97 \pm 0.4$ & $31.7 \pm 3.2 \mathrm{ka}$ \\
\hline GU 2.25 Normanby R. FP $150 \mathrm{~cm}$ & $38 \pm 2$ & $41 \pm 1$ & $35 \pm 2$ & $54 \pm 1$ & $346 \pm 8$ & $2.58 \pm 0.22$ & $1.49 \pm 0.15$ & $575 \pm 80 \mathrm{a}$ \\
\hline GU 2.26 Normanby R. FP $1100 \mathrm{~cm}$ & $48 \pm 2$ & $49 \pm 1$ & $39 \pm 3$ & $68 \pm 1$ & $470 \pm 11$ & $3.21 \pm 0.27$ & $1.84 \pm 0.25$ & $575 \pm 95 \mathrm{a}$ \\
\hline GU 2.27 Normanby R. FP $1150 \mathrm{~cm}$ & $54 \pm 2$ & $48 \pm 1$ & $44 \pm 3$ & $74 \pm 1$ & $444 \pm 10$ & $3.30 \pm 0.29$ & no $D_{\mathrm{e}}$ & no date \\
\hline GU 2.28 Normanby R. FP $1200 \mathrm{~cm}$ & $84 \pm 3$ & $55 \pm 1$ & $53 \pm 3$ & $71 \pm 1$ & $415 \pm 9$ & $3.41 \pm 0.31$ & $2.22 \pm 0.22$ & $645 \pm 90 \mathrm{a}$ \\
\hline GU 2.29 Normanby R. FP $1290 \mathrm{~cm}$ & & $59 \pm 1$ & $57 \pm 3$ & $67 \pm 2$ & $386 \pm 10$ & $3.15 \pm 0.28$ & $11.73 \pm 0.36$ & $3.73 \pm 0.37 \mathrm{ka}$ \\
\hline GU 2.30 Normanby S.VFPit $170 \mathrm{~cm}$ & $79 \pm 3$ & $82 \pm 1$ & $70 \pm 4$ & $134 \pm 2$ & $1078 \pm 23$ & $6.43 \pm 0.53$ & $7.0 \pm 0.41$ & $1.09 \pm 0.12 \mathrm{ka}$ \\
\hline GU 2.31 Normanby S.VFPit $1130 \mathrm{~cm}$ & $53 \pm 3$ & $50 \pm 1$ & $46 \pm 3$ & $84 \pm 1$ & $813 \pm 18$ & $4.50 \pm 0.36$ & $13.56 \pm 0.45$ & $3.01 \pm 0.28 \mathrm{ka}$ \\
\hline GU 2.32 NormanbyS.VFPit $1220 \mathrm{~cm}$ & $32 \pm 2$ & $24.1 \pm 0.4$ & $28.3 \pm 2.5$ & $47 \pm 1$ & $765 \pm 17$ & $3.47 \pm 0.25$ & $10.5 \pm 0.4$ & $3.03 \pm 0.27 \mathrm{ka}$ \\
\hline GU 2.36 West Normanby Bench 55 & $21.9 \pm 1.6$ & $23.3 \pm 0.4$ & $30 \pm 2$ & $31 \pm 1$ & $558 \pm 13$ & $2.68 \pm 0.20$ & $0.0455 \pm 0.0179$ & $17 \pm 7 \mathrm{a}$ \\
\hline GU 2.37 West Normanby Bench 125 & $36 \pm 2$ & $34 \pm 1$ & $38 \pm 2$ & $44 \pm 1$ & $542 \pm 12$ & $2.98 \pm 0.23$ & $0.093 \pm 0.025$ & $31 \pm 9 \mathrm{a}$ \\
\hline GU 2.38 West Normanby Bench 170 & $39 \pm 2$ & $36 \pm 1$ & $38 \pm 2$ & $51 \pm 1$ & $495 \pm 11$ & $2.95 \pm 0.24$ & $0.195 \pm 0.0359$ & $66 \pm 13 \mathrm{a}$ \\
\hline GU 2.39 West Normanby Bench 220 & $42 \pm 2$ & $40 \pm 1$ & $41 \pm 3$ & $53 \pm 1$ & $492 \pm 11$ & $3.02 \pm 0.25$ & $0.174 \pm 0.022$ & $58 \pm 9$ a \\
\hline GU 2.40 East Normanby x-sec 1-200 & $32 \pm 2$ & $29.8 \pm 0.5$ & $36 \pm 2$ & $40 \pm 1$ & $535 \pm 12$ & $2.83 \pm 0.22$ & $15.5 \pm 0.6$ & $5.48 \pm 0.50 \mathrm{ka}$ \\
\hline GU 2.41 East Normanby x-sec 2-70 & $34 \pm 2$ & $32 \pm 1$ & $29.5 \pm 2.3$ & $41 \pm 1$ & $529 \pm 13$ & $2.78 \pm 0.21$ & $2.89 \pm 0.07$ & $1.04 \pm 0.09 \mathrm{ka}$ \\
\hline GU 2.42 East Normanby x-sec 2-170 & $31 \pm 2$ & $32 \pm 0$ & $36 \pm 2$ & $38 \pm 1$ & $580 \pm 12$ & $2.94 \pm 0.22$ & $5.25 \pm 0.25$ & $1.79 \pm 0.17 \mathrm{ka}$ \\
\hline GU 2.43 East Normanby x-sec 3-60 & $28.8 \pm 1.6$ & $25.7 \pm 0.4$ & $22.9 \pm 1.8$ & $31 \pm 0$ & $459 \pm 10$ & $2.34 \pm 0.18$ & $0.235 \pm 0.095$ & $100 \pm 40 \mathrm{a}$ \\
\hline GU 2.44 East Normanby x-sec 3-130 & $28.3 \pm 1.4$ & $26.3 \pm 0.4$ & $24.9 \pm 1.7$ & $32 \pm 1$ & $484 \pm 10$ & $2.43 \pm 0.18$ & $0.75 \pm 0.074$ & $310 \pm 40 \mathrm{a}$ \\
\hline GU 2.45 East Normanby x-sec 3-190 & $29.3 \pm 1.7$ & $28.5 \pm 0.4$ & $28.2 \pm 2.1$ & $36 \pm 1$ & $487 \pm 11$ & $2.54 \pm 0.20$ & $0.83 \pm 0.03$ & $330 \pm 30 \mathrm{a}$ \\
\hline GU 2.46 East Normanby x-sec 3-310 & $37 \pm 2$ & $32 \pm 0$ & $31 \pm 2$ & $41 \pm 1$ & $480 \pm 11$ & $2.64 \pm 0.21$ & $0.91 \pm 0.04$ & $340 \pm 30 \mathrm{a}$ \\
\hline GU 2.47 East Normanby x-sec 4-20 & $34 \pm 2$ & $33 \pm 0$ & $44 \pm 2$ & $39 \pm 1$ & $457 \pm 10$ & $2.76 \pm 0.22$ & $0.001 \pm 0.01$ & $0 \pm 4 \mathrm{a}$ \\
\hline GU 2.48 East Normanby x-sec 4-120 & $37 \pm 2$ & $33 \pm 1$ & $33 \pm 2$ & $43 \pm 1$ & $488 \pm 11$ & $2.74 \pm 0.22$ & $0.003 \pm 0.014$ & $1 \pm 5 \mathrm{a}$ \\
\hline GU 2.49 NKCP1-95 & $56 \pm 2$ & $39 \pm 1$ & $35 \pm 3$ & $64 \pm 1$ & $478 \pm 11$ & $3.15 \pm 0.27$ & $3.35 \pm 0.4$ & $1.06 \pm 0.16 \mathrm{ka}$ \\
\hline GU 2.50 NKCP1-185 & $54 \pm 2$ & $39 \pm 1$ & $36 \pm 3$ & $68 \pm 1$ & $504 \pm 12$ & $3.27 \pm 0.28$ & $3.75 \pm 0.17$ & $1.15 \pm 0.12 \mathrm{ka}$ \\
\hline GU 2.51 NKCP1-400 & $38 \pm 2$ & $34 \pm 1$ & $28.9 \pm 2.3$ & $54 \pm 1$ & $397 \pm 9$ & $2.57 \pm 0.22$ & $5.18 \pm 0.26$ & $2.02 \pm 0.21 \mathrm{ka}$ \\
\hline GU 2.52 NKCP2-117 & $54 \pm 2$ & $38 \pm 1$ & $27.5 \pm 2.5$ & $67 \pm 1$ & $497 \pm 12$ & $3.14 \pm 0.26$ & $3.76 \pm 0.85$ & $1.20 \pm 0.29 \mathrm{ka}$ \\
\hline GU 2.53 NKCP3-35 & $66 \pm 2$ & $34 \pm 1$ & $27.3 \pm 2.5$ & $62 \pm 1$ & $476 \pm 11$ & $3.07 \pm 0.26$ & $3.49 \pm 0.16$ & $1.13 \pm 0.11 \mathrm{ka}$ \\
\hline GU 2.54 NKCP3-165cm Below Salt & $31 \pm 2$ & $28.4 \pm 0.4$ & $30.0 \pm 1.8$ & $49 \pm 1$ & $422 \pm 9$ & $2.55 \pm 0.21$ & $4.53 \pm 0.39$ & $1.78 \pm 0.22 \mathrm{ka}$ \\
\hline GU 2.55 Kalpowar Bench 30 & $25.3 \pm 1.3$ & $23.2 \pm 0.3$ & $25.5 \pm 1.5$ & $34 \pm 0$ & $211 \pm 5$ & $1.73 \pm 0.15$ & $0.105 \pm 0.025$ & $61 \pm 15 \mathrm{a}$ \\
\hline GU 2.56 Kalpowar Bench 155 & $16.7 \pm 1.1$ & $17.5 \pm 0.3$ & $19.3 \pm 1.4$ & $26.7 \pm 0.4$ & $104 \pm 3$ & $1.18 \pm 0.10$ & $0.23 \pm 0.03$ & $195 \pm 31$ a \\
\hline GU 2.57 Kalpowar Bench 200 & $18.1 \pm 1.8$ & $16.5 \pm 0.3$ & $20.5 \pm 2.3$ & $22.2 \pm 0.4$ & $164 \pm 5$ & $1.29 \pm 0.11$ & $0.21 \pm 0.04$ & $163 \pm 34 a$ \\
\hline GU 2.58 Kalpowar Upper125 & $19.0 \pm 1.6$ & $16.3 \pm 0.3$ & $24.4 \pm 2.2$ & $22.0 \pm 0.4$ & $134 \pm 5$ & $1.27 \pm 0.11$ & $1.52 \pm 0.12$ & $1.20 \pm 0.15 \mathrm{ka}$ \\
\hline GU 2.59 Kalpowar Upper 200 & $33 \pm 3$ & $34 \pm 1$ & $36 \pm 3$ & $50 \pm 1$ & $364 \pm 10$ & $2.52 \pm 0.22$ & $7.9 \pm 0.5$ & $3.14 \pm 0.35 \mathrm{ka}$ \\
\hline GU 2.60 Carrols Xing Bench 70 & 2 & .3 & .9 & 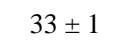 & $2 \xi$ & 15 & 009 & $5 \pm 5 \mathrm{a}$ \\
\hline
\end{tabular}




\begin{tabular}{cccccccc} 
GU 2.61 Carrols Xing Bench 130 & $26.2 \pm 1.5$ & $22.4 \pm 0.4$ & $24.2 \pm 1.9$ & $35 \pm 1$ & $294 \pm 7$ & $1.94 \pm 0.16$ & $0.06 \pm 0.01$ \\
GU 2.62 Carrols Xing Bench 210 & $36 \pm 2$ & $33 \pm 0$ & $34 \pm 2$ & $50 \pm 1$ & $337 \pm 8$ & $2.43 \pm 0.21$ & $0.16 \pm 0.02$ \\
GU 2.63 Carrols Xing Bench 320 & $34 \pm 1$ & $29.6 \pm 0.4$ & $27.0 \pm 1.5$ & $44 \pm 1$ & $382 \pm 8$ & $2.35 \pm 0.19$ & $3.15 \pm 0.25$ \\
GU 2.64 Carrols Upper Surface 130 & $35 \pm 1$ & $33 \pm 0$ & $29.9 \pm 1.4$ & $49 \pm 1$ & $448 \pm 9$ & $2.68 \pm 0.22$ & $58 \pm 3.4$ \\
\hline
\end{tabular}

Table 3. Summary of aggradation rates measured at all sites.

\begin{tabular}{|c|c|c|c|c|c|c|}
\hline Profile & $\begin{array}{l}\text { Aggradation } \\
\text { Rate } \\
(\mathbf{m m} / \mathbf{y r}) \\
\end{array}$ & $\begin{array}{l}\text { Period } \\
\text { (years } \\
\text { to } \\
\text { present) }\end{array}$ & $\begin{array}{l}\% \text { Fines } \\
\text { (<63 um) }\end{array}$ & Location & Stream & $\begin{array}{l}\text { Catchment } \\
\text { Area }\left(\mathrm{km}^{2}\right)\end{array}$ \\
\hline \multicolumn{7}{|l|}{ Benches } \\
\hline West Normanby & 31 & 60 & 23 & $15.77^{\circ} \mathrm{S}, 144.97^{\circ} \mathrm{E}$ & Normanby R & 840 \\
\hline Battle Camp Crossing & 20 & 160 & 28 & $15.29^{\circ} \mathrm{S}, 144.84^{\circ} \mathrm{E}$ & Normanby R & 2302 \\
\hline KPWN5 & 2.3 & 660 & 55 & $15.68^{\circ} \mathrm{S}, 144.95^{\circ} \mathrm{E}$ & Normanby R & 1043 \\
\hline Lower Kalpowar & 13 & 180 & 16 & $14.91^{\circ} \mathrm{S}, 144.21^{\circ} \mathrm{E}$ & Normanby R & 12857 \\
\hline Carrolls Crossing & 32 & 60 & 50 & $15.74^{\circ} \mathrm{S}, 144.68^{\circ} \mathrm{E}$ & Laura R & 301 \\
\hline & \\
\hline $\begin{array}{l}\text { Inset Floodplain } \\
\text { KPWN3 }\end{array}$ & $<0.09$ & $\sim 50$ & & $15.68^{\circ} \mathrm{S}, 144.95^{\circ} \mathrm{E}$ & Normanby R & 1043 \\
\hline \multicolumn{7}{|l|}{ East Normanby } \\
\hline Point Bar & 1000 & 2 & 38 & $15.76^{\circ} \mathrm{S}, 145.01^{\circ} \mathrm{E}$ & East Normanby R & 301 \\
\hline Scroll 1 & 10 & 100 & 14 & $15.76^{\circ} \mathrm{S}, 145.01^{\circ} \mathrm{E}$ & East Normanby $\mathrm{R}$ & 301 \\
\hline Scroll 2 & 1.3 & 1800 & 25 & $15.76^{\circ} \mathrm{S}, 145.01^{\circ} \mathrm{E}$ & East Normanby $\mathrm{R}$ & 301 \\
\hline Scroll 3 & 0.36 & 5500 & 25 & $15.76^{\circ} \mathrm{S}, 145.01^{\circ} \mathrm{E}$ & East Normanby R & 301 \\
\hline \multicolumn{7}{|l|}{ Coastal Floodplain } \\
\hline NKCP1 & 0 & 500 & 95 & $14.52^{\circ} \mathrm{S}, 143.97^{\circ} \mathrm{E}$ & na & na \\
\hline NKCP2 & 0 & 570 & 95 & $14.50^{\circ} \mathrm{S}, 144.00^{\circ} \mathrm{E}$ & na & na \\
\hline \multicolumn{7}{|l|}{ Proximal Floodplains } \\
\hline Kalpowar Upper Surface & 1 & 1000 & 45 & $14.91^{\circ} \mathrm{S}, 144.21^{\circ} \mathrm{E}$ & Normanby R & 12857 \\
\hline Carrolls Crossing Upper Surface & 0 & $\sim 5000(?)$ & - & $15.74^{\circ} \mathrm{S}, 144.68^{\circ} \mathrm{E}$ & Laura R & 301 \\
\hline KPWN1 & $\sim 0$ & $\sim 5000(?)$ & - & $15.68^{\circ} \mathrm{S}, 144.95^{\circ} \mathrm{E}$ & Normanby R & 1043 \\
\hline Bizant Gully & $0-0.3$ & 2500 & 85 & $14.69^{\circ} \mathrm{S}, 144.14^{\circ} \mathrm{E}$ & na & na \\
\hline Bizant River & 0.8 & 2200 & 85 & $14.68^{\circ} \mathrm{S}, 144.14^{\circ} \mathrm{E}$ & Bizant R & 13080 \\
\hline IBA16 & $<0.2$ & 2500 & 10 & $14.70^{\circ} \mathrm{S}, 143.90^{\circ} \mathrm{E}$ & Unnamed & 43 \\
\hline NSVF1 & 0.5 & 3000 & 30 & $15.39^{\circ} \mathrm{S}, 144.85^{\circ} \mathrm{E}$ & Unnamed & 2 \\
\hline MRFP & 0.2 & 4800 & 25 & $14.72^{\circ} \mathrm{S}, 143.98^{\circ} \mathrm{E}$ & Morehead R & 3816 \\
\hline \multirow[t]{2}{*}{ NRFP } & 0.25 & 400 & 90 & $14.65^{\circ} \mathrm{S}, 144.18^{\circ} \mathrm{E}$ & Normanby $R$ & 13097 \\
\hline & 0.33 & & & & & \\
\hline
\end{tabular}


Page $\mathbf{4 3}$ of $\mathbf{4 3}$

\section{Highlights}

- We incorporate in-channel depositional surfaces into a sediment budget for the Normanby River

- We compare aggradation rates on in-channel depositional surfaces, floodplains and the coastal plain

- We show in-channel depositional surfaces to be very significant components of the sediment budget

- We suggest aggradation on in-channel depositional surfaces has accelerated since European Settlement

- In-channel depositional surfaces play an important role in reducing sediment export 


\section{Accepted Manuscript}

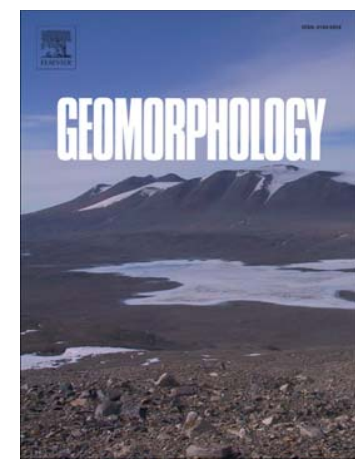

Age, distribution, and significance within a sediment budget, of in-channel depositional surfaces in the Normanby River, Queensland, Australia

\section{T.J. Pietsch, A.P. Brooks, J. Spencer, J.M. Olley, D. Borombovits \\ PII: $\quad$ S0169-555X(15)00120-8 \\ DOI: $\quad$ doi: $10.1016 /$ j.geomorph.2015.01.038 \\ Reference: $\quad$ GEOMOR 5117}

To appear in: $\quad$ Geomorphology

Received date: 12 December 2013

Revised date: $\quad 20$ January 2015

Accepted date: $\quad 23$ January 2015

Please cite this article as: Pietsch, T.J., Brooks, A.P., Spencer, J., Olley, J.M., Borombovits, D., Age, distribution, and significance within a sediment budget, of in-channel depositional surfaces in the Normanby River, Queensland, Australia, Geomorphology (2015), doi: 10.1016/j.geomorph.2015.01.038

This is a PDF file of an unedited manuscript that has been accepted for publication. As a service to our customers we are providing this early version of the manuscript. The manuscript will undergo copyediting, typesetting, and review of the resulting proof before it is published in its final form. Please note that during the production process errors may be discovered which could affect the content, and all legal disclaimers that apply to the journal pertain. 